SONIA I. OCAÑA RUIZ

FACULTAD DE FILOSOFÍA Y LETRAS, UNAM

\title{
Marcos "enconchados":
}

\section{autonomía y apropiación de formas japonesas \\ en la pintura novohispana}

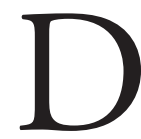

EBIDO AL SINGULAR USO DEL NÁCAR, las pinturas "enconchadas" han llamado la atención de numerosos investigadores en los últimos Ioo años. La problemática de estas obras se ha planteado de maneras distintas, lo cual revela la variedad de concepciones artísticas de los autores que las han estudiado. En sus inicios, la historia del arte novohispano tuvo dificultades para abordar los objetos que, como los "enconchados", hicieron suyos elementos ajenos a la producción artística europea.

Ahora bien, con el paso del tiempo, se advirtió que el arte novohispano no se limitó a reproducir los planteamientos europeos, sino que los usó como punto de partida para elaborar los propios. Las pinturas "enconchadas" ofrecen un interesante ejemplo de esto, pues poseen particularidades que nos acercan a la manera en que los novohispanos construyeron su identidad artística. De ahí la importancia de estudiarlas y de revisar los modos en que los investigadores las han conceptualizado.

Hasta mediados del siglo xx, hubo problemas para hallar el lugar de los "enconchados" en su ámbito de origen: el contexto pictórico novohispano. Se pensó que las obras se relacionaban con el arte chino, el japonés, el mesoamericano y el flamenco. En la actualidad se conocen cerca de 250 pinturas de este tipo. Sin embargo, hasta I980 se tenían noticias de unas I50, en su mayoría 


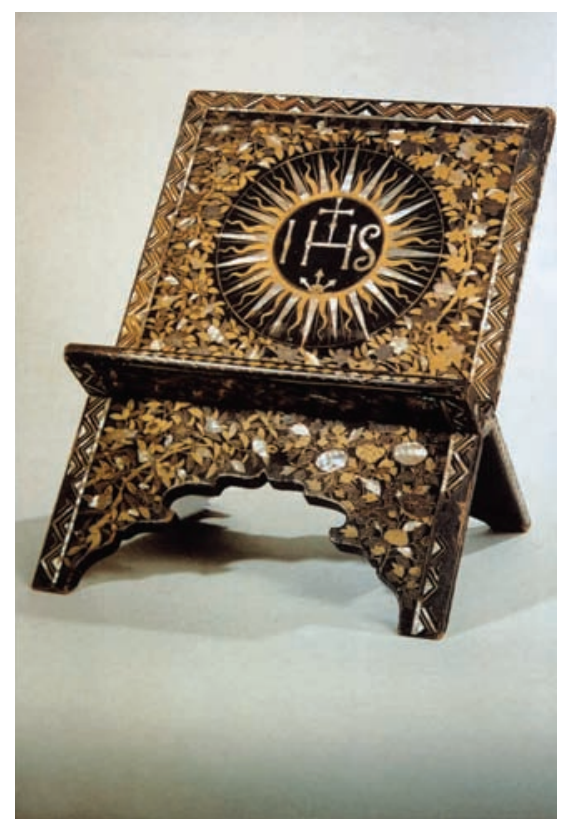

I. Atril japonés de laca namban con incrustaciones de concha, $c a$. I600. Tomado del catálogo Important Japanese Works of Art, Christie's Londres, I4 y I5 de junio de I989, lote 236, p. I 47. Copyright Christie's Images, Ltd. [2007]

pertenecientes a series de seis, I 2 y 24 tablas. ${ }^{\mathrm{I}}$ Llama la atención que, a pesar del escaso número de obras conocidas, se vertieran sobre ellas ideas tan ajenas entre sí.

I. El libro de Marta Dujovne, Las pinturas con incrustaciones de nácar, México, Universidad Nacional Autónoma de México-Instituto de Investigaciones Estéticas, I984, registró I64 obras. Antes de su publicación se conocían 69 obras de la colección del Museo de América de Madrid, que habían sido reproducidas y comentadas por María Concepción García Sáiz, La pintura colonial en el Museo de América, Los enconchados, Madrid, Patrimonio Cultural, I980, vol. II. Dicha colección incluye una serie de 24 tablas de la Conquista de México, de Miguel y Juan González, de 1698 (fig. 4), así como tres series anónimas más: una de seis tablas sobre el mismo tema, otra también de seis tablas sobre la Vida de la Virgen (fig. 7) y una más de 24 sobre la Vida de Cristo (fig. 6). Se sabía, asimismo, de una serie de I 2 tablas de las Alegorías del Credo firmada por Miguel González y dividida entre el Banco Nacional de México y el Instituto Nacional de Antropología e Historia (en adelante INAH), y de dos series de 24 tablas cada una de la Conquista de México, una firmada por el mismo artista, de la que se conservan 22 tablas en el Museo de Bellas Artes de Buenos Aires (fig. 3), y otra que se creía anónima y había pertenecido al conde de Moctezuma. Se tenía también noticia de una serie anónima de seis tablas del mismo tema, dividida entre la colección Mayer y el INAH. A dichas series se sumaban unas I5 obras documentadas por Manuel Toussaint en "La pintura con incrustaciones de concha nácar en la Nueva España", Anales del Instituto de Investigaciones Estéticas, México, Universidad Nacional Autónoma de México-Instituto de Investigaciones Estéticas, vol. V, núm. 20, 1952, pp. 5-20, y Martín Soria, "Painting in 
2. Detalle de un tríptico japonés de laca namban con incrustaciones de concha, periodo Momoyama. Tomado del catálogo Japanese Works of Art, Christie's Londres, 9 y Io de noviembre de 1988, lote 674, p. 243. Copyright Christie's Images, Ltd. [2007]

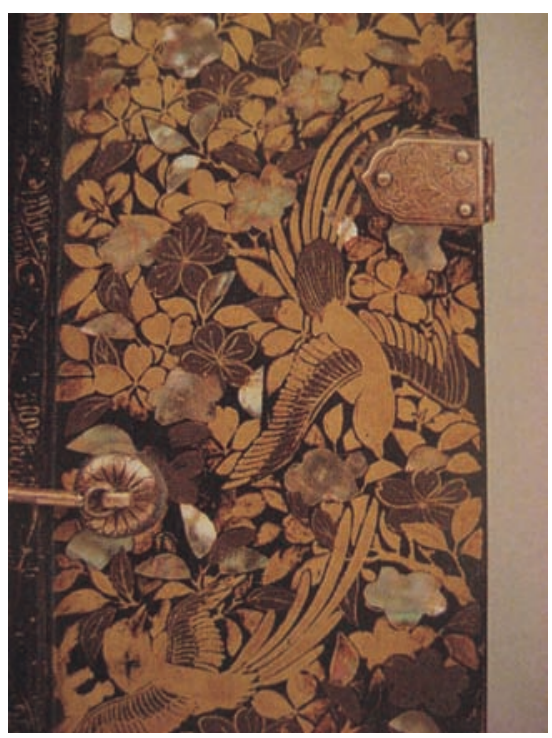

Los "enconchados" no sólo se distinguen por el uso del material, sino también por sus ricos marcos, cuya elaborada ornamentación permite afirmar que fueron especialmente valorados. Los marcos muestran, además, singular cercanía con los objetos de los que se tomó el uso del nácar. Así pues, deben ser tenidos en cuenta para comprender mejor la problemática de la producción.

\section{Las primeras referencias}

En la primera mitad del siglo xx, las pinturas "enconchadas" fueron tema de textos que abordaron el lugar donde se habían hecho, el origen de sus autores, su técnica y las obras con que se relacionaban por el uso del nácar. Se planteó que el empleo de ese material se había tomado de objetos de origen asiático, mesoamericano, o de ambos. Sin embargo, ningún autor ahondó en el asunto.

Entre las primeras obras enconchadas que se conocieron, destacan dos series, ambas de 24 tablas, que representan la Conquista de México. Una se hallaba en el Museo de Bellas Artes de Buenos Aires (fig. 3), donde aún permanece, y la otra

Spanish America", en Art and Architecture in Spain and Portugal and their American Dominions, I500-I800, Baltimore, Penguin Books, I959, p. 313. 


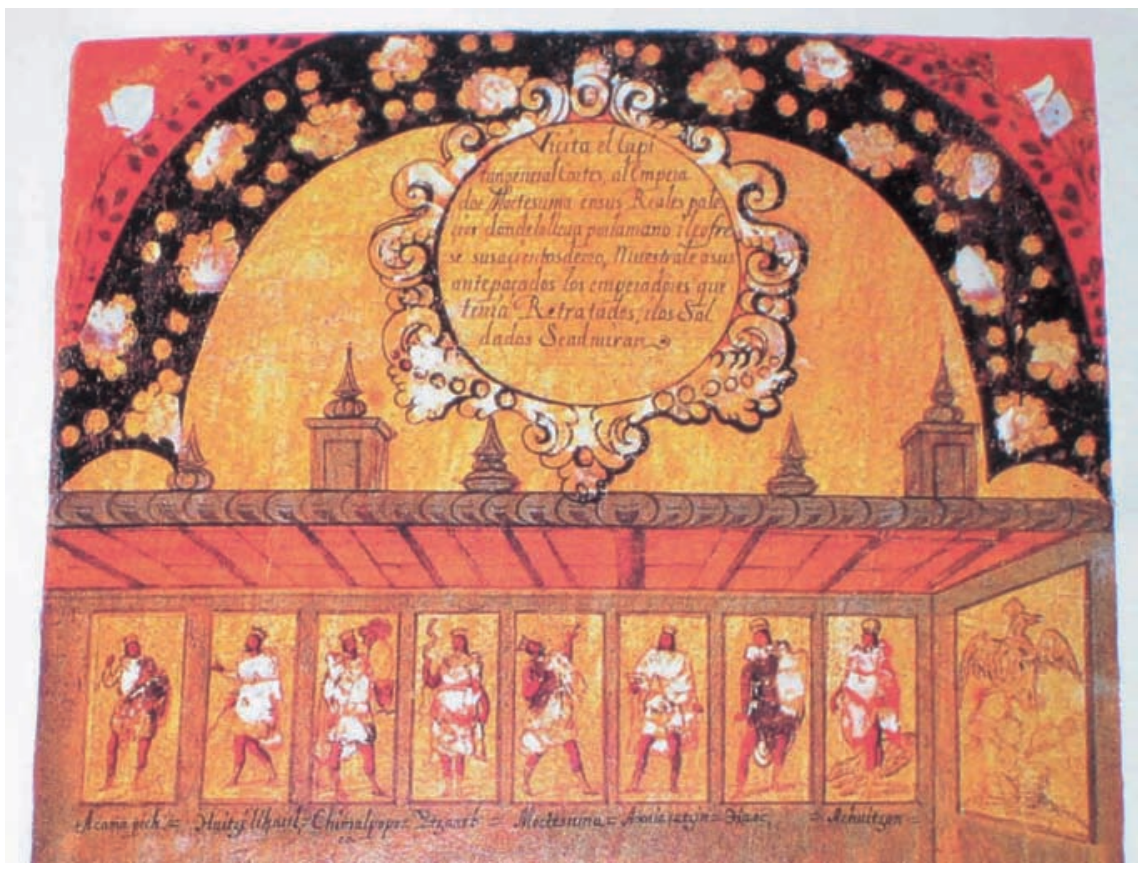

3. Miguel González, detalle de "Visita Cortés el palacio de Moctezuma", de la serie Conquista de México, finales del siglo XviI, óleo, temple y embutidos de nácar, $100 \times 54 \mathrm{~cm}$, Museo de Bellas Artes, Buenos Aires. Imagen tomada de Los pinceles de la historia. El origen del reino de la Nueva España, México, Consejo Nacional para la Cultura y las Artes/Instituto Nacional de Bellas Artes, I999, p. I23.

se encontraba en el Museo Arqueológico de Madrid, y actualmente se conserva en el Museo de América de la misma ciudad (fig. 4). La serie de Buenos Aires muestra la firma de Miguel González, mientras que la de Madrid está signada tanto por ese artista como por Juan González. Sin embargo, no había noticias previas de ninguno de los dos creadores. ${ }^{2}$

2. En I93 I se dio a conocer la mencionada serie de in tablas de las Alegorías del Credo, de Miguel González. Cfr. "Miguel González", Contemporáneos, México, núm. 35, abril de I931, pp. 83-84. En 1937, Genaro Estrada documentó obras que entonces estaban en el Museo Arqueológico de Madrid. Se trata de una Virgen de Balvanera de Juan González y de la mencionada serie anónima de seis tablas de la Vida de la Virgen, y de seis tablas con figuras de santos, de las que Estrada comentó que eran de Juan González. La Virgen de Balvanera y la serie de la Vida de la Virgen se encuentra actualmente en el Museo de América de Madrid. Ignoro cuáles sean las seis tablas con 
4. Miguel y Juan González, detalle de "Entrada de Cortés en México por la Calzada de San Antonio Abad", de la serie Conquista de México, 1698, óleo, temple y embutidos de nácar, $97 \times 53 \mathrm{~cm}$, Museo de América, Madrid. Imagen tomada de Artes de México. Tesoros de México en España, núm. 22, México, invierno de 1993-I994, p. 3I.

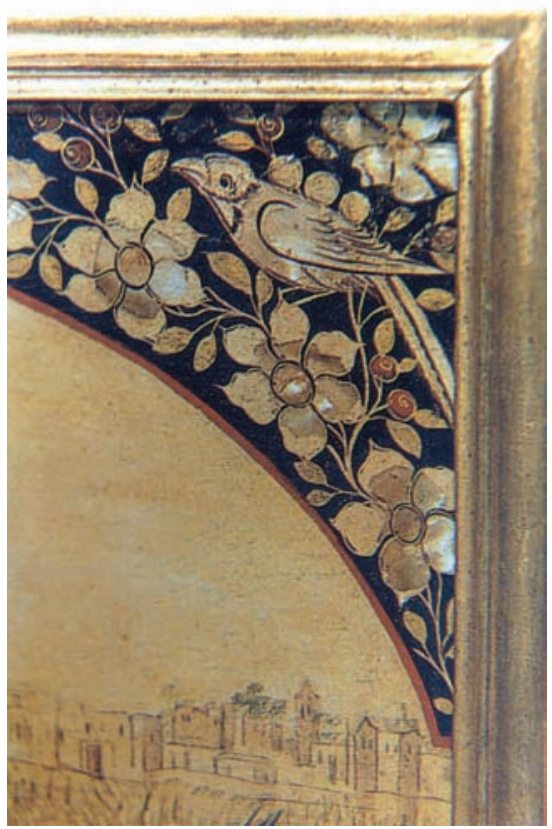

Uno de los temas que más preocupaba a los investigadores mexicanos era el lugar donde se habían confeccionado las obras. La representación de la Conquista de México sugería su origen novohispano, pero el hecho de que en España hubiera muchos más ejemplares que en México causaba desconcierto.

Alfonso Reyes y Genaro Estrada se interesaron en los "enconchados” hacia I930, como resultado de su labor diplomática, uno de cuyos ejes fue el discurso nacionalista emanado del triunfo de la Revolución. ${ }^{3}$ Ambos autores dieron

figuras de santos a las que se refirió el autor. Véase Genaro Estrada, El arte mexicano en España, México, Porrúa, 1937, pp. 23-25.

3. Alfonso Reyes fue embajador en Argentina de 1927 a 1930, y nuevamente de 1936 a 1937. El texto en que dio a conocer la serie "enconchada" del Museo de Bellas Artes de Buenos Aires es de I93I. Por su parte, Estrada fue embajador en España de 1932 a I935. Sus textos sobre "enconchados" son de 1933 y 1937. Ambos tuvieron una estrecha relación personal. En una carta del 2I de febrero de 1931, Reyes le escribió a Estrada: "Le mando una joya para Contemporáneos: la Conquista de México de Miguel González [...] Aquí [en Río de Janeiro] no tengo manera de saber ni averiguar nada de Miguel González. Si Ud. sabe algo, que de seguro lo sabrá, tómese el trabajo de añadirlo, de su propia minerva, al final de mi breve noticia”. Cfr. Con leal franqueza. 
especial importancia a la representación de la Conquista de México. ${ }^{4}$ Si bien Reyes se limitó a señalar que las tablas "hace mucho tiempo merecieron haber interesado la opinión de los mexicanos", 5 Estrada abundó más en el tema. Inicialmente, mencionó sólo a Miguel González como autor de las obras y comentó que éstas posiblemente se habían hecho en España, pero en su segundo texto se refirió también a Juan González y señaló que los trabajos se habían realizado en México. ${ }^{6}$ Sin embargo, no discutió la problemática de la producción.

Por su parte, tanto Manuel Romero de Terreros como Manuel Toussaint, pioneros de la investigación del arte novohispano, prestaron gran atención al empleo de la concha. El primero de ellos se refirió a las obras en su estudio sobre Las artes industriales en la Nueva España, donde las comentó junto a los muebles incrustados de nácar, marfil, plata y carey, así como a las lacas michoacanas. ${ }^{7}$

El mismo autor advirtió que se trataba de cuadros en tabla, "con un maqueado producido por la incrustación en la tabla de trozos de nácar, lo que proporciona un oriente y transparencia especial a lo pintado". ${ }^{8}$ Sin embargo, no hizo referencias a otras pinturas. Cabe suponer que, pese a su interés en el arte novohispano, su concepción de la pintura derivó del academicismo del siglo XIx. Es decir que para Romero de Terreros el uso del nácar habría restado validez a los "enconchados" como pinturas, de ahí que las documentara junto a los muebles y las lacas.

Correspondencia entre Alfonso Reyes y Genaro Estrada, III. 1930-1937, Serge I. Zaïtzeff (comp. y notas), México, El Colegio Nacional, 1994, p. I 2.

4. Reyes informó: "El Museo Nacional de Bellas Artes, de Buenos Aires, custodia una curiosísima colección de cuadros que hace mucho tiempo merecieron haber interesado la opinión de los mexicanos. Trátase de veintidós cuadros de Miguel González, pintados al óleo sobre telas estucadas en tablas, y realzados con incrustaciones de nácar. Representan veintidós episodios de la Conquista de México, y tienen singular interés". Cfr. Alfonso Reyes, "La 'Conquista de México (I519-I52I)’ por Miguel González”, Contemporáneos, México, núm. 34, marzo de I93 I, pp. 206-207. Estrada añadió que: "En Madrid se encuentran dos colecciones [...] de tablas de la conquista de México [...] Parece que su autor, Miguel González, español, hacía estos trabajos entre los últimos años del siglo xvıı y los primeros del xvıı". Cfr. Genaro Estrada, "Las tablas de la Conquista de México en las colecciones de Madrid”, en Cuadernos Mexicanos de la Embajada de México en España, Madrid, 1933, p. 7.

5. Reyes, "La 'Conquista...", op. cit., p. 206.

6. Estrada, El arte mexicano..., op. cit., pp. 21-25.

7. Manuel Romero de Terreros, Las artes industriales en la Nueva España, México, Pedro Robredo, I923, pp. I37-I40.

8. Ibidem, p. 138 . 
Toussaint expuso puntos de vista encontrados en su artículo de 1952, el primero dedicado íntegramente a los "enconchados". 9 Cabe recordar que Toussaint fue autor de un estudio fundamental sobre la pintura novohispana. ${ }^{\text {Io }}$ Así pues, su postura acerca de los “enconchados” merece especial atención. Según Toussaint, pese a que no se conservan obras firmadas por las familias de pintores más reconocidas de finales del siglo XVII, dichas familias sin duda incursionaron en la producción. ${ }^{\text {II }}$

Con la salvedad de Nicolás Correa, sobrino de Juan Correa, no hay indicios de que tales familias se vincularan con este tipo de trabajos, pero sí lo hicieron algunos pintores poco conocidos. ${ }^{\mathrm{I} 2}$ Así pues, Toussaint atinó al advertir la estrecha relación entre los "enconchados" y la restante producción pictórica novohispana.

Otro acierto de Toussaint consistió en señalar que estas pinturas se habían hecho "a imitación de las lacas orientales que ofrecían incrustaciones semejantes y que cada año llegaban a México en la famosa 'Nao de China' [...]" I3 Sin embargo, el autor planteó una equívoca relación técnica entre los "enconchados" y las lacas novohispanas de origen mesoamericano. ${ }^{\mathrm{I} 4}$

9. El artículo se publicó apenas tres años antes de la muerte del autor, cuando ya había desarrollado la mayoría de sus investigaciones. Según Toussaint, dicho texto "fue escrito hace mucho tiempo". Cfr. Toussaint, "La pintura...”, op. cit., p. 5. Es posible que el texto se editara tardíamente debido a que el tema supuso grandes dificultades para el autor. Al respecto, véase Guillermo Tovar, "Los artistas y las pinturas con incrustaciones de concha nácar en México", en La concha nácar en México, México, Gutsa, I990, pp. I06-i io, así como María Concepción García Sáiz, "Precisiones al estudio de la obra de Miguel González", en Manuel Toussaint. Su proyección en la historia del arte mexicano. Coloquio Internacional Extraordinario, México, Universidad Nacional Autónoma de México-Instituto de Investigaciones Estéticas, I992, p. I05.

Io. El autor mencionó los "enconchados" en dicho estudio. Cfr. Manuel Toussaint, Pintura colonial en México, Xavier Moyssén (ed.), México, Universidad Nacional Autónoma de MéxicoInstituto de Investigaciones Estéticas, I982, p. I45.

I I. Toussaint, "La pintura...", op. cit., p. 7.

I2. Véase Soria, op. cit., p. 3I3, así como Dujovne, op. cit., y María Concepción García Sáiz y Juan Miguel Serrera, "Aportaciones al catálogo de enconchados", Cuadernos de Arte Colonial, Madrid, Museo de América, núm. 6, I990, pp. 55-86.

I3. Toussaint, "La pintura...", op. cit., p. Iо.

I4. Según Toussaint, "La pintura que se usaba en estos cuadros embutidos de concha se llamaba 'maque' es decir, algo que imitaba a la laca [...] el maque era en absoluto independiente de la concha y consistía en bruñir o 'charolar' la pintura por diversos procedimientos, algunos de los cuales eran de procedencia indígena, para dar el aspecto terso y esmaltado de las lacas." Cfr. ibidem, pp. 9-10. Estos planteamientos se retomaron posteriormente. Véase Marita Martínez del 
El supuesto vínculo entre los "enconchados" y las lacas novohispanas carece de sustento, pues en ambos tipos de objetos se utilizaron técnicas distintas y se produjeron en lugares diferentes. El que Toussaint los relacionara permite suponer que, sin advertirlo, halló más fácil fundamentar el origen novohispano de las pinturas "enconchadas" a partir del mestizaje con objetos provenientes de Mesoamérica, y no de Asia.

Paradójicamente, Toussaint tuvo grandes dificultades para hallar el lugar de los "enconchados" en su ámbito de origen. Si bien advirtió numerosísimos indicios de que se habían confeccionado en la Nueva España, dedicó buena parte de su texto a defender la idea de que los especialistas Miguel y Juan González habían sido españoles. ${ }^{15}$ Es posible que fuera la falta de evidencias de una relación entre las lacas de origen mesoamericano y los "enconchados" lo que llevó a Toussaint a suponer que estas pinturas se habían realizado en la Península. Ahora bien, el autor parece haber estado consciente de la debilidad de sus argumentos en pro del supuesto origen español de las obras, pues admitió la posibilidad de que fueran novohispanas. ${ }^{16}$

Cabe suponer que la vacilación de Toussaint respecto a la procedencia de los "enconchados" obedeció al uso del nácar. ${ }^{17} \mathrm{Su}$ insistencia en la procedencia española de los González sugiere que el autor — quien conocía a fondo la producción pictórica novohispana y no así la española - tuvo problemas para admitir la idea de que la pintura local se había apropiado del uso de la concha y de la ornamentación de las lacas asiáticas. ${ }^{18}$ Toussaint fue el último autor en

Río y Teresa Castelló, Biombos mexicanos, México, Instituto Nacional de Antropología e Historia, I970, p. 4I, así como Dujovne, op. cit., p. I4.

I5. Toussaint, "La pintura...", op. cit., pp. 6, I3, I4, I7-20.

I6. Toussaint señaló: "Yo creo [...] que estos artífices fueron españoles, de la Metrópoli, pero [...] no me causaría el menor asombro que apareciese una prueba documental que echase por tierra mis disquisiciones". Ibidem, p. 6.

I7. Según Toussaint, "Sin duda alguna, si se hiciese una investigación en un archivo de Sevilla, semejante al que yo exploré en México, se encontrarían referencias igualmente numerosas acerca de esta modalidad artística. A tal conclusión me hacen llegar dos circunstancias: la primera que en España existen más cuadros con incrustaciones de concha que en México; la segunda que la siguiente referencia de Palomino (t. I. p. 4I): 'Pintura lignaria. Se hace también con concha'". Cfr. ibidem, p. Io. Es decir, la referencia a ese material en el tratado español hizo creer a Toussaint que el uso de la concha había sido una variante de las concepciones pictóricas peninsulares. Sin embargo, sus argumentos "en pro del espańolismo de los González" abordaron la manera de resolver las figuras, no el empleo del material. $C f$ r. pp. 17-20.

I8. Por otro lado, si bien Toussaint no tuvo noticia de ningún biombo "enconchado", en su texto sobre las pinturas embutidas de concha mencionó los biombos novohispanos: "Otra de 
5. Anónimo, Virgen de Guadalupe, finales del siglo XVII, óleo, temple y embutidos de nácar, $84 \times 60 \times 15 \mathrm{~cm}$, Museo Catedralicio-Diocesano de León, España. Imagen tomada de Iberoamérica mestiza. Encuentro de pueblos y culturas, Madrid, Seacex, 2003, p. 254.

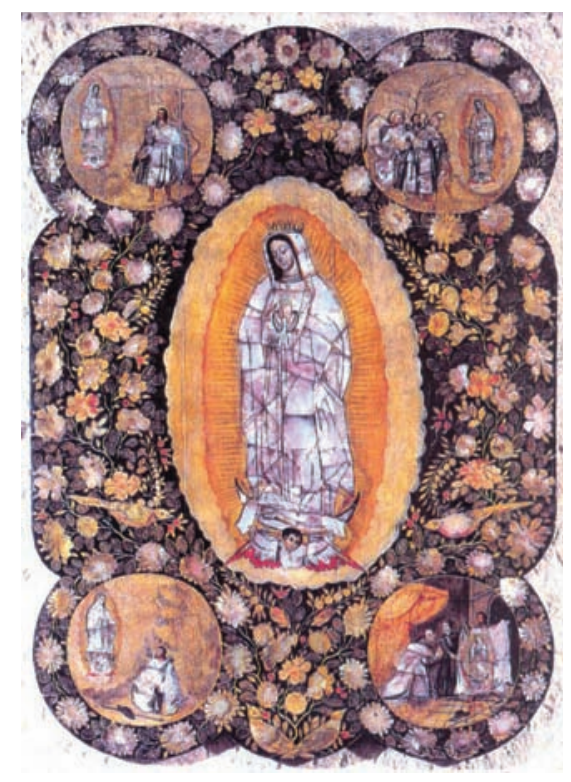

afirmar que las obras se habían hecho en España. Sin embargo, las vacilaciones planteadas en su texto tuvieron un efecto duradero en la historiografía del tema, pues la discusión sobre el origen de los objetos de los que se tomó el uso del nácar se ha prolongado hasta nuestros días.

Ahora bien, los autores no mexicanos siempre afirmaron el origen novohispano de la producción. Tal fue el caso de Miguel Solá, quien, sin embargo, tuvo una perspectiva eurocéntrica que lo llevó a sostener que las obras recordaban la pintura asiática y, a la vez, que sus antecedentes se encontraban en los mosaicos y máscaras con incrustaciones del arte azteca, y en los códices indígenas. ${ }^{19}$

El texto de Solá, de 1935, ofrece un buen ejemplo de las dificultades que para numerosos autores de la primera mitad del siglo xx entrañó la comprensión de las obras transculturizadas. Solá mostró un conocimiento superficial tanto del

las manifestaciones plásticas relacionadas con los pintores que estudiamos es la de los biombos pintados. Conviene pues ensayar un ligero estudio acerca de estos artísticos muebles que, importados de Oriente también, hallaron carta de naturalización entre nosotros y llegaron a ser abundantísimos". Ibidem, p. Iо.

19. Miguel Solá, Historia del arte hispanoamericano, Barcelona, Labor (Biblioteca de Iniciación Cultural, Sección IV, Artes Plásticas), 1935, pp. 99-I00. 
arte mesoamericano como del asiático, además de manifestar desinterés por explicar los términos en que se produjo la relación entre los "enconchados" y las obras tan ajenas a ellos que él mencionó.

Martín Soria tampoco logró identificar los objetos de los que derivó el uso de la concha, pero hizo contribuciones significativas al estudio de las obras. Si bien este autor no tuvo un conocimiento de la pintura novohispana tan erudito como el de Toussaint, fue más preciso que éste en cuanto a los vínculos entre los "enconchados" y la restante producción pictórica novohispana. Su texto de 1959 insertó las obras, con naturalidad, en el contexto pictórico local, y añadió los nombres de Nicolás Correa y Antonio de Santander al catálogo de autores, que hasta entonces se limitaba a los especialistas Miguel y Juan González. ${ }^{20}$

Soria señaló que el empleo de la concha podía ser un remanente de tiempos prehispánicos, sin abundar en el tema. ${ }^{2 \mathrm{I}} \mathrm{Es}$ posible que este investigador, conocedor de la pintura espańola y de la sudamericana, hallara más sencillo fundamentar el uso del nácar a partir de la herencia mesoamericana que de la apropiación local del arte asiático, que apenas empezaba a conocerse. ${ }^{22}$

Ninguno de los autores arriba referidos ahondó en el análisis de la técnica de las obras. Los textos tampoco abordaron los ricos marcos "enconchados". Ambos temas son fundamentales y empezaron a estudiarse a finales del siglo xx, lo cual dio lugar a distintas opiniones que conviene revisar.

20. A la fecha se ignora si Santander, activo en Puebla, efectivamente realizó "enconchados", pues nunca se ha reproducido la Virgen de Balvanera de colección particular, de su autoría, a la que se refirió Soria. Cfr. Soria, op. cit., p. 313. En 1990, Guillermo Tovar se mostró sorprendido de que Soria hubiera afirmado la existencia de dicha obra, aunque reconoció la seriedad del trabajo de ese autor. Véase "Los artistas...", op. cit., pp. I20-I22. El mismo año, Virginia Armella señaló que "la Virgen de Balvanera de la colección Aranda es una pintura sobre tabla magnífica pero no tiene concha, sino gemas pegadas a la orilla de la toca, en el vestido y en todo el ruedo del manto de la Virgen". Cfr. "La influencia asiática", en La concha..., op. cit., p. 83.

2I. Soria mostró gran interés en dar respuesta a la suposición de Toussaint de que las obras eran de origen espańol. Según aquel autor, tanto el estilo de las figuras como el de las firmas remiten a la pintura novohispana. Cfr. Soria, op. cit., p. 3 I 3 .

22. Soria fue editor de The Paintings of Zurbarán, Londres, Phaidon Press, I955, así como autor de La pintura del siglo XVI en Sudamérica, Buenos Aires, Universidad de Buenos Aires-Facultad de Arquitectura y Urbanismo, I956, y de Agustín Esteve y Goya, Valencia, Institución Alfonso el Magnánimo/Diputación Provincial, 1957. 


\section{La técnica}

En los últimos 30 años se ha analizado la técnica de muchos "enconchados", hasta arrojar luz sobre procedimientos y materiales relativos a ellos. ${ }^{23}$ Los resultados de los estudios muestran ciertas variaciones, pero, en conjunto, sugieren que la única diferencia técnica significativa respecto a otras pinturas novohispanas es el embutido de concha. ${ }^{24}$ Cabe señalar que se han estudiado obras con marcos y se ha encontrado que éstos se trabajaron de la misma manera que las superficies pictóricas. Es decir, los marcos fueron hechos por los autores de las pinturas "enconchadas".

Debido al peso del nácar, el soporte utilizado es siempre la tabla que, en ocasiones, se recubre con lienzo. La superficie recibe una base de preparación a la que se añade una sinopia para definir las áreas donde se embutirá la concha. Se dibujan las figuras y, a continuación, se embute el material, adherido con cola animal. ${ }^{25}$ La pintura se aplica en una capa muy delgada que, al parecer,

23. Quiero expresar mi agradecimiento a los investigadores Andrés Escalera, Estefanía Rivas y Dolores Medina, del Museo de América de Madrid, así como a los restauradores Liliana Giorguli y Rolando Araujo, de la Escuela Nacional de Conservación, Restauración y Museografía "Manuel del Castillo Negrete" del InAH, y a Ricardo Pérez, director de Colecciones del Museo Franz Mayer de la ciudad de México, cuya generosa ayuda fue fundamental para desarrollar las hipótesis aquí expuestas.

24. José de Santiago fue el primer autor que analizó la técnica de las obras, y halló datos que fueron confirmados por investigaciones posteriores. Véase José de Santiago, Algunas consideraciones sobre las pinturas enconchadas del Museo Nacional de Historia, México, Instituto Nacional de Antropología e Historia, 1976. En su estudio de 1990, Alejandro Huerta incluyó el análisis de los marcos, así como de los aglutinantes, soslayados en otros estudios. Véase Alejandro Huerta, Análisis de la técnica y material de dos colecciones de pinturas enconchadas, México, Instituto Nacional de Antropología e Historia (Colección Textos Básicos y Manuales), I99i. El trabajo de Andrés Escalera y Estefanía Rivas tiene especial relevancia, pues se basa en el análisis de casi 70 obras. Véase Andrés Escalera y Estefanía Rivas, “Un ejemplo de pintura 'enconchada'. La Virgen de la Redonda: estudio radiográfico", Anales del Museo de América, Madrid, núm. I0, 2002, pp. 291-305, así como Estefanía Rivas, "El empleo de la concha nácar en la pintura virreinal: estudio radiográfico de la colección de pintura 'enconchada' del Museo de América de Madrid”, en Espacio, Tiempo y Forma, Serie VII, Historia del Arte, t. I5, 2002, pp. I47-I67. Véase también María Dolores Medina, "Aspectos técnicos manifestados durante la restauración del enconchado 'San Isidro y el milagro de la fuente' perteneciente al Museo de América de Madrid", Anales del Museo de América, Madrid, núm. 3, 1995, pp. 97-100, y Los enconchados: conservación y restauración de pinturas con incrustaciones de concha, México, Gobierno del Estado de Guerrero, 1986, pp. I4-I8.

25. El procedimiento muestra pequeñas variaciones en las distintas obras analizadas. Cfr. Huerta, op. cit., pp. 29, 3I-32, 34-35, 45-48, así como De Santiago, op. cit., p. 28. 
combina el uso de temple y óleo. ${ }^{26}$ Los pigmentos utilizados son blanco de plomo, blanco de Espańa, cinabrio, minio, ocre amarillo, laca de granza, negro de humo, negro de carbón, sombra natural, sombra tostada, siena natural y siena tostada, todos de uso habitual en la pintura novohispana. ${ }^{27}$

Algunas figuras se delinean en negro o dorado por encima de la capa pictórica, lo que confiere precisión a sus formas a costa del realismo. Para aprovechar al máximo la iridiscencia del nácar, aquella capa debe ser ligera, lo que limita el naturalismo de las figuras. De ahí el contraste entre las soluciones de los "enconchados" y las de las otras pinturas novohispanas, a pesar de la estrecha relación técnica existente entre unas y otras.

La capa de barniz que recubre ciertas obras es inusualmente gruesa. ${ }^{28}$ Se ha sugerido que técnicamente las obras se relacionan con las lacas por el uso del barniz. ${ }^{29}$ Sin embargo, un San Francisco Xavier embarcándose a Asia, firmado en I703 por Juan González, de colección particular, parece haber prescindido de barniz..$^{30}$ Además, un San Isidro y el milagro de la fuente, anónimo, del Museo de América de Madrid, posee una gruesa capa de barniz que no es original, pues al limpiarla salieron a la luz efectos ópticos que habían permanecido ocultos. ${ }^{3 \mathrm{I}} \mathrm{El}$ tema reviste gran importancia y deberá ser objeto de más análisis. Sin embargo, hasta ahora la idea de que técnicamente las obras se vinculan con las lacas carece de sustento.

En ocasiones las obras comentadas presentan polvo de oro, ya sea mezclado con los pigmentos o suspendido en la capa de barniz. ${ }^{32} \mathrm{Al}$ igual que ocurre

26. En una serie de seis tablas de la Conquista de México que se divide entre el INAH y el Museo Franz Mayer de la ciudad de México, José de Santiago halló que la técnica combina óleo y barniz. Cfr. De Santiago, op. cit., p. 28. Años más tarde, Alejandro Huerta analizó la misma serie y encontró el uso predominante del temple, si bien las encarnaciones se hicieron al óleo. $C f$ r. Huerta, op. cit., p. 50. Dicha serie también fue estudiada por un grupo coordinado por Agustín Espinosa. El texto publicado por dicho grupo omitió referirse a los aglutinantes. Cfr. Los enconchados..., op. cit., pp. I4-I8.

27. Huerta, op. cit., pp. 48-50.

28. Ibidem, p. 55 .

29. Julieta Ávila, El influjo de la pintura china en los enconchados de Nueva España, México, Instituto Nacional de Antropología e Historia (Colección Obra Diversa), 1997, pp. 57-58.

30. Clara Bargellini, "Saint Francis Xavier Embarking for Asia", en Painting a New World. I520-I810, Denver, Denver Art Museum, 2004, p. I87. Bargellini seńaló que la fuente de esta información es el reporte de conservación inédito elaborado por un equipo encabezado por Liliana Giorguli. Cfr. p. 293, n. 5 .

31. Medina, op. cit., pp. 99-100.

32. Cfr. ibidem, p. 98, así como Huerta, op. cit., p. 52. 
con la mayoría de los materiales mencionados, el polvo de oro se usó en otras pinturas novohispanas. ${ }^{33}$ Cabe suponer que su empleo en los "enconchados" obedeció a que, junto con el nácar, proporcionó brillo a las obras.

La composición química del nácar es ajena a los materiales tradicionalmente usados en la pintura novohispana. Por esa razón, los "enconchados" supusieron un reto técnico complejo que los artistas sólo resolvieron virtuosamente en casos excepcionales. La conservación de los "enconchados" entrańa numerosas dificultades, pues los embutidos de concha se desprenden con facilidad, lo que obliga a intervenir las obras con cierta frecuencia. Esto hace difícil saber cuál fue su aspecto original.

Aún hay mucho que precisar respecto a la técnica de las obras, cuyo estudio ha dado lugar a puntos de vista contrastantes. Así pues, las investigaciones técnicas deben nutrirse del análisis historiográfico. De cualquier modo, el estudio de los textos publicados permite descartar que los "enconchados" se relacionen técnicamente con objetos distintos a las pinturas novohispanas.

\section{Los marcos "enconchados"}

El hecho de que la técnica de los marcos sea la misma que la de las pinturas "enconchadas" demuestra que unas y otras partes de las obras están estrechamente relacionadas, lo cual resulta común en otras pinturas de la época. ${ }^{34}$ En la Nueva España, los marcos fueron muy valorados. Sin embargo, ese tipo de obras aún no han sido objeto de estudios particulares.

En la actualidad, la idea de marco suele asociarse a los marcos exentos, estructuras autónomas unidas a las pinturas (véanse figs. 6-9). En Europa, los marcos exentos se consolidaron en el siglo Xv, con el auge de las pinturas de caballete. ${ }^{35}$ Ahora bien, tanto en Europa como en la Nueva Espańa, dichos

33. Abelardo Carrillo y Gariel, Técnica de la pintura de Nueva España, México, Universidad Nacional Autónoma de México-Instituto de Investigaciones Estéticas, 1983 (Ia. ed. 1946), pp. $8 \mathrm{I}-82$.

34. Ejemplo de esto es una Santa Rosa de Lima, de Juan Correa, de I67I, conservada en una colección particular de la ciudad de México y reproducida en Elisa Vargaslugo et al., Juan Correa su vida y su obra. Repertorio pictórico, Segunda parte, México, Universidad Nacional Autónoma de México-Instituto de Investigaciones Estéticas, I99I, t. IV, fig. I.

35. Jill Dunkerton et al., Giotto to Dürer: Early Renaissance Painting in the National Gallery, New Haven/Londres, National Gallery London, 1994, pp. I55-156. 


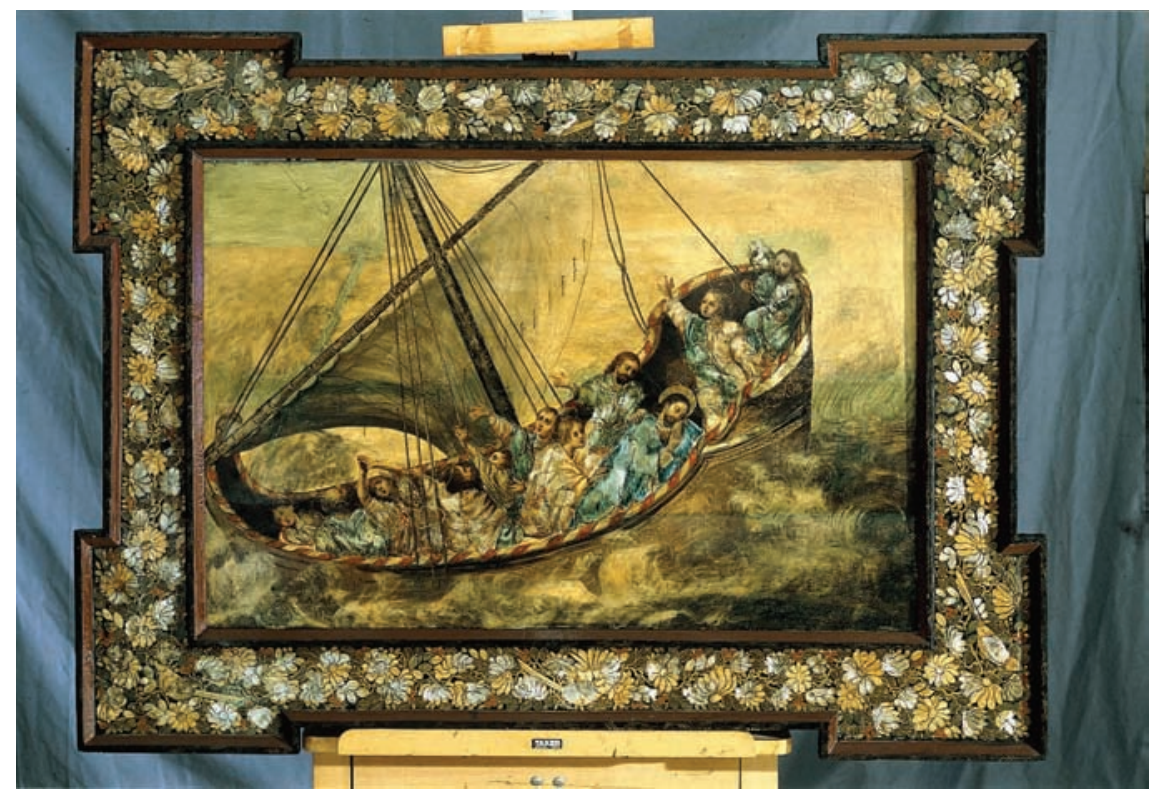

6. Anónimo, marco de "La tempestad calmada", serie de la Vida de Cristo, finales del siglo XviI, óleo, temple y embutidos de nácar, $69 \times 102 \mathrm{~cm}$, Museo de América, Madrid. Foto: Joaquín Otero Úbeda.

marcos coexistieron con las cenefas, o marcos pintados en el borde de las superficies pictóricas (véanse figs. 3 y 4). Los "enconchados" muestran ambos tipos de marcos, cuya ornamentación exhibe las mismas características, por lo que aquí se estudiarán indistintamente.

Numerosas pinturas embutidas de nácar carecen de marcos "enconchados", ya sea porque poseen otro tipo de marcos o porque han llegado a nuestros días desprovistas de ellos. Más aún, muchas partidas documentales relativas a "enconchados" omitieron referirse a los marcos, o bien los describieron sin mencionar el nácar. ${ }^{36}$ Es decir, abundantes pinturas "enconchadas" prescindieron de los marcos confeccionados con la misma técnica. Ahora bien, las obras más notables que han llegado a nosotros poseen, con pocas excepciones, marcos pintados y embutidos de concha, cuyo minucioso trabajo imprime a las obras buena parte de su atractivo.

36. Véase, en este mismo texto, "Los alcances de la producción", pp. I3I-I39. 
A finales del siglo xx, cuando los "enconchados" empezaron a ser objeto de estudios particulares, se advirtió la importancia de su ornamentación, a menudo reservada a los marcos. La primera mención del tema data de 1965 , cuando Antonio Bonet se refirió al único biombo "enconchado" original que se conoce. Bonet acertó al señalar que la cenefa de la obra recuerda los tapices de Bruselas de los siglos XVI y XVII. ${ }^{37}$ Ahora bien, la mayoría de los marcos "enconchados" son más cercanos a modelos ajenos a ese ámbito.

Posteriormente, Teresa Castelló y Marita Martínez del Río señalaron que las tablas de la Conquista de México de Miguel González, del Museo de Bellas Artes de Buenos Aires (fig. 3), están "terminadas con doble cenefa de flores y frutas, una sobre fondo negro y otra con guía sobre fondo rojo". ${ }^{38}$ Marta Dujovne se refirió a una serie anónima de seis tablas, del mismo tema, que conserva el Museo de América de Madrid, y advirtió que "cada pintura está enteramente rodeada por una guarda recta, que en el borde superior es el doble de gruesa que en los márgenes laterales, y en el borde inferior es aún más ancha. Está decorada con frutos y hojas". ${ }^{39}$

En su libro de 1980 sobre los "enconchados" del Museo de América, María Concepción García Sáiz se refirió a una serie de la Vida de Cristo (fig. 6) e informó que "Los marcos que acompañan a los cuadros son de época y están realizados con la misma técnica del enconchado, empleando motivos florales y de aves"..$^{\circ}$ La misma autora comentó también los marcos de una serie de la Vida de la Virgen (fig. 7), así como las cenefas de dos series de la Conquista de México (fig. 4), además de identificar su repertorio y señalar su relación con las pinturas. ${ }^{41}$

37. Antonio Bonet, "Un biombo del siglo xviI", en Boletín del INAH, México, núm. 2I, septiembre de 1965 , p. 36.

38. Castelló y Martínez del Río, op. cit., p. 42. Las autoras también señalaron que las tablas de una serie de la Conquista de México de Miguel y Juan González, del Museo de América de Madrid (fig. 3), están "terminadas por cenefas de flores y pájaros formando arcos", ibidem, p. 43.

39. Dujovne, op. cit., p. 9. Cabe añadir que, en las imágenes reproducidas en su libro, Dujovne incluyó algunos marcos "enconchados" e hizo mención de éstos.

40. García Sáiz, La pintura..., op. cit., p. I04.

4I. García Sáiz comentó que, en la serie anónima de seis tablas de la Vida de la Virgen (fig. 7), "los cuadros conservan los marcos de época y desde el primer momento se encuentran formando unidad [...] los marcos [están] decorados con motivos de flores y de aves y [...] utiliza[n] el enconchado". Ibidem, pp. 87-88. La autora señaló que las tablas de la Conquista de México firmadas por Miguel y Juan González (fig. 4) tienen un enmarque de flores y pájaros. Ibidem, p. 2 I. Respecto a la serie anónima de seis tablas del mismo tema, la autora observó que tiene una franja decorativa con motivos florales. Ibidem, p. 72. 


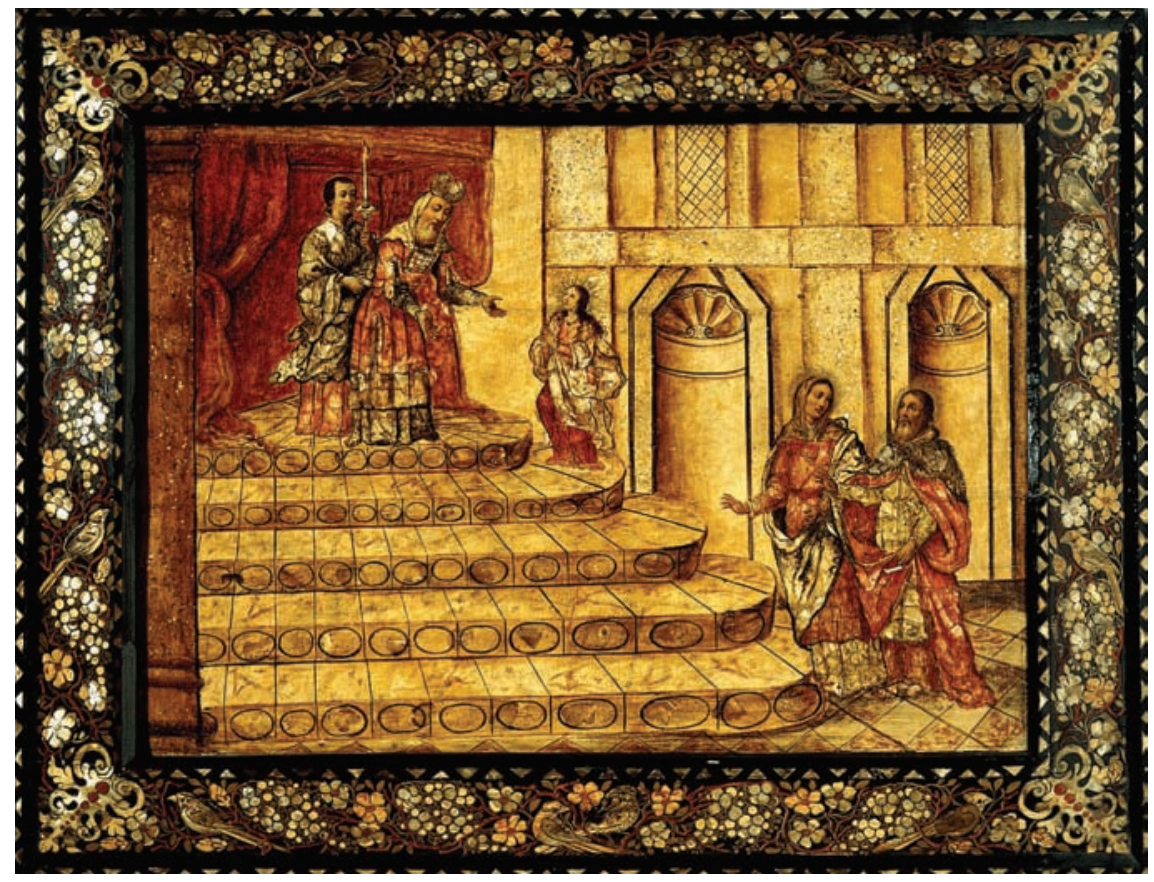

7. Anónimo, marco de "La presentación de la Virgen en el templo", serie de la Vida de la Virgen, finales del siglo xviI, óleo, temple y embutidos de nácar, 6I ×86 cm, Museo de América, Madrid. Foto: Joaquín Otero Úbeda.

En 1994, se reprodujeron a color numerosos "enconchados" con sus marcos, en México en el mundo de las colecciones de arte. Nueva España I, lo que permitió advertir la riqueza de estos últimos. La publicación dedicó a las obras un artículo donde Elisa Vargaslugo se refirió también a los marcos. ${ }^{42}$ Asimismo, se incluyeron numerosas fichas sobre "enconchados", cuyos autores abordaron el mismo tema. Pedro Ángeles mencionó las figuras que pueblan las cenefas de dos series de la Conquista de México del Museo de América de Madrid,43

42. Elisa Vargaslugo, "La pintura de enconchados", en México en el mundo de las colecciones de arte. Nueva España I, México, Azabache, 1994, p. I2I.

43. Al referirse a la primera tabla de la serie de la Conquista de México firmada por Miguel y Juan González, del Museo de América, Ángeles advirtió que "se repetirá en todas las pinturas de la serie [...] la guía floral que sirve de marco a la composición, la cual no siempre se observa completa. En este marco, donde se utilizó abundantemente la madreperla para los pétalos de las flores, destacan 
mientras que María Eugenia Rodríguez comentó la influencia chinesca de los marcos de la serie de la Vida de Cristo (fig. 6) de dicha colección. ${ }^{44}$ Nuria Salazar y Gustavo Curiel, a su vez, se refirieron a la relación entre las pinturas y los marcos. ${ }^{45}$ Curiel, por su parte, enfatizó la riqueza del marco de la Virgen de Guadalupe de un misterioso Rodolfo, que se conserva en el Museo Casa Natal de Jovellanos, en Gijón. ${ }^{46}$

Los marcos "enconchados" también se evocaron en El marco en España, del mundo romano al inicio del modernismo, de María Pía Timón. ${ }^{47}$ La autora acertó al señalar la relación entre los marcos y ciertas lacas japonesas. Tal nexo fue originalmente planteado por Rodrigo Rivero Lake, quien sin embargo soslayó a los marcos. ${ }^{48}$

En 2003, se dio a conocer un San Francisco Xavier embarcándose a Asia, de Juan González, de 1703, que se conserva en una colección particular. Clara Bargellini mencionó el marco de la obra y señaló su relación con la pintura y su excepcional riqueza. La misma autora observó que las aves que pueblan dicho

en su parte superior un par de aves que parecen picar algún fruto". $C f r$. Pedro Ángeles, "Número I. Serie de la conquista de México I", en México en el mundo..., op. cit., p. I26.

44. María Eugenia Rodríguez, "Adoración de los Magos", en México en el mundo..., op. cit., p. 142.

45. Cfr. Nuria Salazar, "Abrazo en la puerta dorada", en México en el mundo..., op. cit., p. I38, así como "San José con el Niño", en México en el mundo..., op. cit., p. I49, y Gustavo Curiel, "Virgen de Guadalupe con las cuatro apariciones", en México en el mundo..., op. cit., p. I82. Salazar señaló que "es característico de la pintura enconchada que en el marco se empleen los mismos materiales — generalmente con diseño floral". Cfr. "San José con el Niño", en México en el mundo..., op. cit., p. I49.

46. Curiel, op. cit., p. I82.

47. María Pía Timón Tiemblo, El marco en España del mundo romano al inicio del modernismo, Madrid, PEA/Adhisa/4 Ingletes, 2002, pp. 269-270.

48. Rodrigo Rivero Lake, La visión de un anticuario, México, Américo Arte, 1997, pp. 246248. El tema se discute más adelante en este texto. Véase "La relación con el arte namban. Una familiarización misteriosa”, pp. I27-I3I. Timón también mencionó Michoacán como uno de los centros de manufactura de "enconchados". Cfr. Timón, op. cit., p. 269. Ahora bien, la producción fue capitalina. Véase, en este mismo texto, "Los 'enconchados' y la concepción de la pintura en la Nueva España”, pp. I24-I26. Timón hizo recordar los comentarios sobre los muebles americanos de María Paz Aguiló Alonso, "El coleccionismo de objetos procedentes de ultramar a través de los inventarios de los siglos XVI y Xvıı”, en Relaciones artísticas entre España y América, Madrid, Consejo Superior de Investigaciones Científicas-Centro de Estudios Históricos-Departamento de Historia del Arte "Diego Velásquez", 1990, p. I30. 
marco son muy detalladas — algo excepcional en este tipo de obras - y parecen nativas de América. ${ }^{49}$

En Nácar en manos otomies, de 2004, Enriqueta M. Olguín señaló el parecido entre la ornamentación de los objetos incrustados de concha que actualmente producen las comunidades otomíes de Hidalgo y los marcos "enconchados"; además, describió minuciosamente varios de estos últimos y mostró mucho interés en su técnica. ${ }^{50}$

Cabe señalar que la profusión de figuras de los repertorios que circularon en la Nueva España estuvo ausente de los marcos "enconchados", que suelen estar poblados por flores, hojas, aves y racimos de uvas dorados y recortados sobre un fondo negro (véanse figs. 3-9). Pese a las múltiples referencias al tema, aún no se han explicado las razones por las que la mayoría de los marcos muestran dichas soluciones. Por otro lado, al margen del uso de la concha y de la rica ornamentación, los "enconchados" son pinturas, por lo que conviene revisar su papel en el contexto pictórico novohispano.

\section{Los "enconchados" y la concepción de la pintura en la Nueva España}

A finales del siglo XVII, cuando la producción de "enconchados" estaba en su apogeo, los pintores novohispanos lucharon por reivindicar su oficio. ${ }^{\text {II }}$ En la Nueva España ni siquiera los pintores más destacados tuvieron el reconocimiento del que ciertos artistas gozaron en las cortes europeas. Ahora bien, la pintura novohispana gozó de libertad para hacer las experimentaciones

49. Bargellini, op. cit., p. I87. El marco también se comenta en mi texto "Mother of Pearl Inlaid Frames: The Use of Japanese Ornamentation in the Paintings of New Spain", en Asia and Spanish America: Trans-Pacific Artistic and Cultural Exchange I500-1850, Denver, Denver Art Museum, en prensa.

50. Enriqueta M. Olguín, Nácar en manos otomíes, México, Universidad Nacional Autónoma de México-Instituto de Investigaciones Estéticas/Gobierno del Estado de Hidalgo-Consejo Estatal para la Cultura y las Artes, 2004, pp. 36-50.

5I. Las ordenanzas reales del gremio de pintores se dictaron por primera vez en I557, y nuevamente en I686. Según ha señalado Rogelio Ruiz Gomar, a finales del siglo xviı, el "principal problema que aquejaba al gremio de pintores y doradores [era] la competencia desleal de los advenedizos [...] Por ello se insistirá tanto [...] en la formación dentro del gremio y en la necesidad de obtener el rango de maestro". Cfr. Rogelio Ruiz Gomar, "El gremio y la cofradía de pintores en la Nueva España”, en Juan Correa: su vida y su obra, t. III, Cuerpo de documentos, México, Universidad Nacional Autónoma de México-Instituto de Investigaciones Estéticas, I99I, pp. 209-2 I0. 
8. Agustín del Pino, detalle de la Virgen de Guadalupe, principios del siglo xvıII, óleo, temple y embutidos de nácar, $70 \times 50 \mathrm{~cm}$. Colección Museo Franz Mayer, ciudad de México. Foto: Sonia Ocaña.

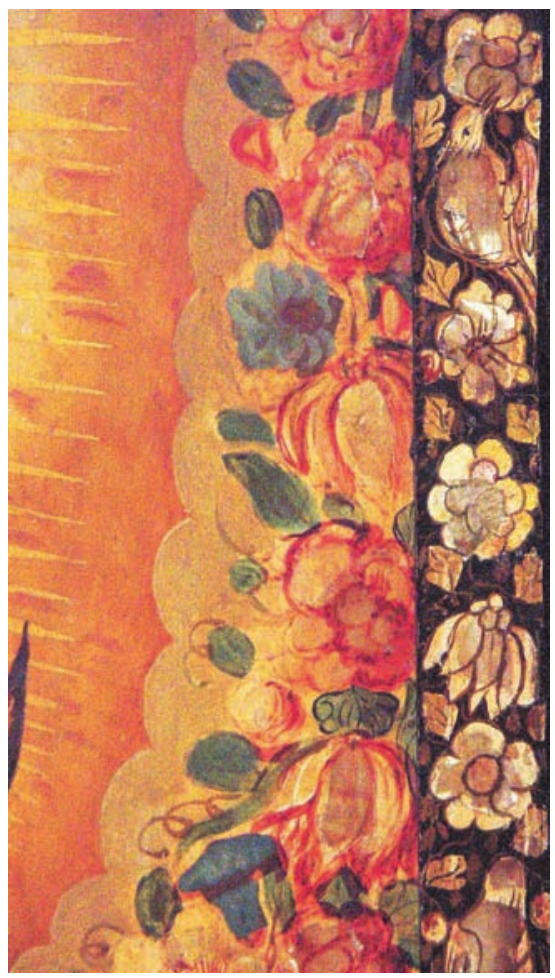

técnicas que en el siglo XVI dieron lugar a la plumaria y, en el XVII, a los "enconchados".

Esto reviste especial interés si se toma en cuenta que la pintura novohispana tuvo lugar en un ámbito gremial y se rigió por ordenanzas cuyo principal cometido fue preservar la tradición pictórica europea. Sin embargo, en la segunda mitad del siglo XVII, cuando los "enconchados" se hallaban en desarrollo, el gremio de pintores había perdido fuerza, de modo que el oficio de pintor era ejercido por algunos personajes que no habían sido formados en talleres acreditados, al lado de maestros examinados. ${ }^{52}$ La técnica híbrida de las obras se vio favorecida por el hecho de que la pintura de la época no siguió al pie de la letra lo dispuesto en las ordenanzas.

Ahora bien, de acuerdo con la información documental, Tomás, Miguel y Juan González, especialistas en pinturas embutidas de nácar, fueron recono- 
cidos por el gremio de pintores al poco tiempo de que se dictaron las nuevas ordenanzas, en I686.53 Un documento capitalino de r689 menciona a "Tomás González, Maestro de Pintor de Maque y vecino de esta Ciudad [...] y Miguel González, Oficial de dicho Arte de Pintor, su hijo mayor", 54 y otro de 1699 a "[Juan] González, Maestro de Pintor", quien se obliga "a hacer y entregar [...] trece Láminas de Pintura y embutido" 55 para cierto personaje.

La expresión "pintor de maque" demuestra que hubo cierta relación entre el trabajo de los especialistas en "enconchados" y algún tipo de lacas. ${ }^{56}$ Ahora bien, sólo un documento empleó dicha expresión, pues el especialista Juan González se denominó simplemente "maestro de pintor". Es decir que, se enfatizó la actividad pictórica, al margen del trabajo "de maque".

En esa época, los novohispanos usaron el término "maque" para referirse tanto a las lacas asiáticas como a las de la tierra, técnicamente ajenas entre sí. ${ }^{57}$ Así pues, no sorprende que Toussaint y otros autores hayan planteado la relación con ambos tipos de lacas. Sin embargo, la técnica de las obras es fiel a la tradición pictórica novohispana, salvo por el uso de la concha.

Los "enconchados" se hicieron en la ciudad de México, donde no se realizaron lacas. Por otro lado, las lacas asiáticas tienen un origen vegetal y requieren una materia prima ajena a la Nueva España. ${ }^{8}$ Así pues, la referencia al maque no implica un vínculo técnico con algún tipo de lacas. Los novohispanos usaron el término "maque" a propósito de estas obras para aludir a la relación formal existente entre los marcos "enconchados" y ciertas lacas japonesas.

53. Guillermo Tovar, "Documentos sobre 'enconchados' y la familia mexicana de los González", Cuadernos de Arte Colonial, Museo de América, núm. I, I986, p. Ior. El nombre y el oficio de Tomás González se conocieron cuando Tovar publicó los documentos mencionados. Hasta ahora no se conocen obras firmadas por Tomás González.

54. Idem. Otro documento del mismo año cita a "Tomás González, Maestro de Pintor y vecino de esta Ciudad”. Las cursivas son mías.

55. Ibidem, p. I02. Las cursivas son mías.

56. Cabe añadir que, en ocasiones, las pinturas embutidas de nácar se denominaron "láminas de concha y maque". Véase Toussaint, "La pintura...", op. cit., pp. 8-9, así como Gustavo Curiel, "El efímero caudal de una joven noble. Inventario y aprecio de los bienes de la marquesa doña Teresa Francisca María de Guadalupe Retes Paz Vera (ciudad de México, 1695)”, Anales del Museo de América, Madrid, núm. 8, 2000, p. 77.

57. Véase Sonia Pérez Carrillo y Carmen Rodríguez de Tembleque, "Influencias orientales y europeas", en Lacas mexicanas, México, Museo Franz Mayer/Artes de México (Colección Uso y Estilo), I997, p. 3 I.

58. Al respecto, véase, por ejemplo, George Kuwayama, Far Eastern Lacquer, Los Angeles, Los Angeles County Museum of Art, I982. 


\section{La relación con el arte namban. Una familiarización misteriosa}

Es significativo que el nácar fuera el único material con que se embutieron las pinturas "enconchadas". El uso exclusivo de la concha distingue a estas obras de otros objetos embutidos de la época en que también se usó hueso, marfil, carey, metal y madera. Esto sugiere que la selección del nácar obedeció a la deliberada evocación de objetos que utilizaron ese material.

En 1997, Rodrigo Rivero Lake identificó las lacas japonesas de exportación, hoy llamadas namban, de las que se tomó el uso del nácar (figs. I y 2).59 Sin embargo, aún hace falta comprender los términos en que se estableció el vínculo entre los "enconchados" y dichas lacas. El tema se puede abordar desde una nueva perspectiva si se toman en cuenta los marcos.

El término namban significa "bárbaros del sur" y los japoneses lo emplearon para referirse a los europeos en la segunda mitad del siglo XVI, cuando los portugueses se asentaron en el archipiélago asiático. Las lacas namban estuvieron controladas por los portugueses y se hicieron expresamente para la exportación al mercado occidental a finales del siglo XVI y principios del XVII. ${ }^{60}$

Las obras poseen fondos negros y figuras doradas y embutidas de concha, de contornos muy precisos. El repertorio se compone de flores de otońo y hojas, pero en ocasiones incluye aves y racimos de uvas, así como motivos geométricos. ${ }^{61}$ Es decir que su parecido con los marcos "enconchados" comprende, además de los embutidos de nácar, el repertorio, la paleta y el énfasis a la línea - aunque no la técnica, el tipo de objeto ni el tratamiento de las figuras.

Así, son los marcos, más que las pinturas, las partes de los "enconchados" que permiten afirmar que esta producción se apropió, específicamente, de las soluciones de las lacas namban. Ahora bien, no hay ninguna relación técnica entre las obras japonesas y las novohispanas. La materia prima de las lacas nam-

59. Rivero Lake, op. cit., pp. 246-248. El autor volvió a abordar el tema en su libro El arte namban en el México virreinal, México, Turner, 2005.

60. Véase Oliver Impey y Christiaan Jörg, Japanese Export Lacquer, I580-1850, Amsterdam, Hotei 2005, así como María Helena Mendes Pinto, Lacas namban em Portugal, Lisboa, Inapa, I990, y Gauvin Alexander Bailey, Art on the Jesuit Missions in Asia and Latin America, I542-1773, University of Toronto Press, I999.

61. Las figuras mencionadas son las más numerosas. Sin embargo, en ocasiones también se incluyen otras. Véase Impey y Jörg, op. cit., pp. 77-8I. 
ban es la resina del árbol rhus vernicifera, nativo de Japón. ${ }^{62}$ Las obras se hicieron en talleres especializados, pues el material es muy difícil de trabajar. ${ }^{63}$

Los marcos "enconchados" se apropiaron del repertorio de las lacas namban a partir de las concepciones pictóricas novohispanas. El empleo novohispano de la palabra "maque" en relación con los "enconchados" sugiere que las lacas namban se distinguieron tan bien que a finales del siglo XviI, cuando la producción japonesa tenía décadas de haber concluido, la expresión "pintor de maque" estaba vigente porque se seguía identificando con ella la ornamentación de las lacas namban, que las obras novohispanas habían hecho suyas.

El vínculo entre los "enconchados" y el arte namban hace imprescindibles las referencias a los pocos conocidos nexos entre la Nueva España y Japón. No hay duda de que entre las mercancías asiáticas embarcadas cada año en Manila se contaron numerosas obras japonesas, pues esa nación tuvo una importante producción artística destinada al mercado occidental. ${ }^{64}$

A principios del siglo XVII, cuando el gusto por las lacas namban estaba en su apogeo, los gobernantes japoneses intentaron establecer contactos mercantiles con la Nueva España. ${ }^{65}$ Asimismo, las autoridades novohispanas mostraron interés por el comercio con Japón. ${ }^{66}$ Sin embargo, ello no fructificó, pues tuvo lugar cuando Japón estaba consolidando su unidad nacional y las autoridades veían con recelo la creciente influencia de los europeos católicos en su territorio. ${ }^{67}$

62. Idem.

63. Idem.

64. Véase Francisco Santiago Cruz, Relaciones diplomáticas entre la Nueva España y Japón, México, Jus, I964, así como Ángel Núñez Ortega, Noticia histórica de las relaciones políticas y comerciales entre México y el Japón durante el siglo XVII, México, Secretaría de Relaciones Exteriores (Archivo Histórico Diplomático, 2), 1923, y Gustavo Curiel, "Los biombos novohispanos: escenografías de poder y transculturación en el ámbito doméstico", en Viento detenido. Mitologías e historias en el arte del biombo, México, Museo Soumaya, 1999.

65. Iyeyasu, el gobernante de Japón, declaró en una carta dirigida al gobernador de Luzón, que "Nada satisfaría tanto mis deseos como ver bajeles mercantiles poniendo en frecuente comunicación mi país con la Nueva España. Y al sentir así no me mueve únicamente el interés del Japón, sino que de igual manera me incita vuestro provecho. Muchos de los vuestros me han afirmado que para ellos sería una considerable ventaja contar con un puerto en el Kwanto [provincias contiguas a la capital, Edo] que diera abrigo a sus naves en las borrascas, e igualmente me han manifestado el gusto con que verían a las embarcaciones japonesas hacer el viaje entre el Kwanto y la Nueva España. Con grande anhelo quedo esperando vuestra respuesta”. Cfr. Cruz, op. cit., p. I5.

66. Ibidem, pp. 19-20.

67. Curiel, "Los biombos...", op. cit., pp. I5. 
9. Anónimo, Virgen de Guadalupe, óleo, temple y embutidos de nácar, $28 \times 19.5 \mathrm{~cm}$, Museo de América, Madrid. Imagen tomada de María Pía Timón Tiemblo, El marco en España del mundo romano al inicio del modernismo, Madrid, PEA/ Adhisa/4 Ingletes, 2002, p. 268.

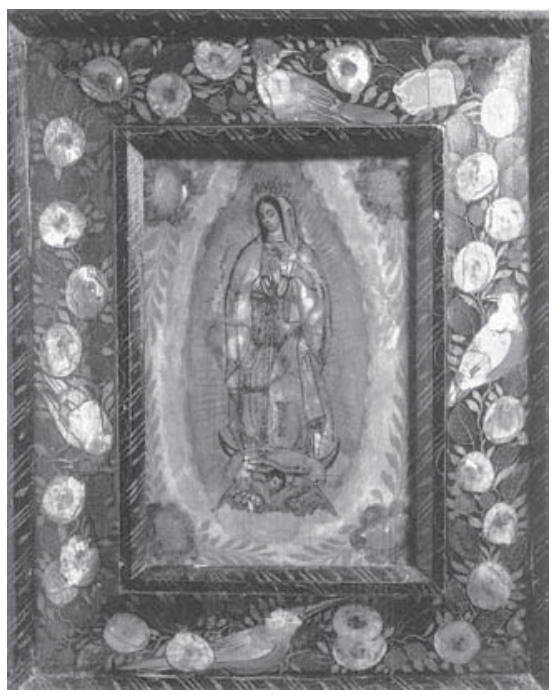

Con todo, los novohispanos, especialmente los capitalinos, debieron de conocer gran número de lacas namban a la llegada de las dos embajadas japonesas que visitaron el virreinato en 1610 y I6I $4 .{ }^{68}$ La primera vino acompañando a Rodrigo de Vivero, sobrino del virrey Luis de Velasco y ex gobernador de Manila, quien había naufragado frente a las costas japonesas al navegar de regreso a la Nueva España. ${ }^{69}$ Por su parte, la embajada de I6r 4 tocó la Nueva España de paso rumbo a Europa, su destino final. $7^{\circ}$

Las lacas namban gozaron de enorme éxito en el mercado occidental. En nuestros días, esa buena fortuna resulta muy difícil de advertir en el ámbito local, pues las obras se han perdido y los documentos a menudo omitieron referirse al origen de las lacas. ${ }^{71}$ Además, al mencionarse los objetos asiáticos, con

68. Ibidem, pp. I3-18.

69. Véase Manuel Romero de Terreros, "Relación del Japón (I609)", Anales del Museo Nacional de Arqueología, Historia y Etnografía, Quinta Época, México, Talleres Gráficos de la Nación, I934, t. I, pp. 67-III.

70. Miguel León-Portilla, "La embajada de los japoneses en México, I6I4. El testimonio en náhuatl del cronista Chimalpahin”, en Estudios de Asia y África, México, El Colegio de México, t. XVI, núm. 2, I98I, pp. 215-24I.

7I. El ex convento de Santa Mónica, en Puebla, conserva una pequeña caja de laca namban de la que no se tiene información. 
frecuencia se empleó en ellos el adjetivo "chino", a pesar de que en ocasiones sus orígenes eran otros. ${ }^{72}$

Las lacas namban se conocieron mejor en Europa que en América. ${ }^{73}$ Sin embargo, en la Nueva Espańa el gusto por las obras tuvo un desarrollo propio, que se prolongó mucho después de que la producción llegó a su fin, pues los marcos "enconchados" de la segunda mitad del siglo XviI hicieron suya la ornamentación de esas lacas. Ahora bien, la apropiación local del repertorio namban tuvo lugar en un contexto de gran interés por la producción japonesa.

Posiblemente, la visita de las embajadas de i6ıo y i6ı4 permitió la llegada de mayor número de obras que en épocas previas, así como de individuos familiarizados con tales obras. Quizá los japoneses que llegaron y se arraigaron en la Nueva España en i6ı impulsaron la recreación del repertorio de las lacas namban, al advertir el interés novohispano por las obras. Dichos japoneses conocieron bien la ornamentación de las lacas namban y quizá intervinieron en las experimentaciones que, al cabo de algún tiempo, dieron lugar a la pintura de "enconchados".

En las primeras décadas del siglo XVII, Japón alcanzó la unificación política de la que carecía una centuria antes, cuando los europeos habían llegado a esa nación y, aprovechando su fragmentación política, lograron un importante papel en el control del mercado exterior. ${ }^{74} \mathrm{~A}$ partir de 1600 , las autoridades japonesas impusieron cada vez mayores medidas restrictivas a los europeos, lo que afectó la producción artística destinada al mercado exterior. ${ }^{75}$

Es decir que, en la época en que las embajadas japonesas llegaron a la Nueva España, la fabricación de lacas namban decaía pese a su enorme éxito anterior. Así, cabe suponer que el interés novohispano por incorporar la rica ornamentación de las obras a su propia producción artística obedeció, en parte, a la dificultad de tener acceso a tantas lacas como se habría deseado.

Cabe insistir en que los "enconchados" se realizaron con las técnicas pictóricas locales y en que la ornamentación se reservó a los marcos, es decir a obras ajenas

72. Gustavo Curiel, “'Al remedo de la China': el lenguaje 'achinado’ y la formación de un gusto dentro de las casas novohispanas", en XXVII Coloquio Internacional de Historia del Arte. Orientes y Occidentes. El arte y la mirada del otro, Gustavo Curiel (ed.), México, Universidad Nacional Autónoma de México-Instituto de Investigaciones Estéticas, 2007, p. 302.

73. Aún se conservan obras en colecciones portuguesas, así como españolas. Véase Mendes Pinto, op. cit., así como Impey y Jörg, op. cit.

74. Véase Mendes Pinto, op. cit., pp. 9-37.

75. Ibidem, pp. 26-37. 
al arte namban. Las pinturas embutidas de concha remiten a las concepciones artísticas novohispanas, independientemente del origen de las obras que inicialmente impulsaron el trabajo. La formación del gusto por los "enconchados" tuvo lugar a lo largo del siglo xvII, en un contexto local que conviene examinar.

\section{Los alcances de la producción}

Muchos de los "enconchados" que se conservan ofrecen testimonio de una producción especializada que respondía a demandas de los grupos de poder novohispanos. Las obras destinadas a las elites locales casi se han perdido, pero conocemos sus características gracias a los numerosos "enconchados" que alcanzaron el siglo xx en colecciones peninsulares de alto nivel. ${ }^{76}$

Algunos documentos españoles mencionaron este tipo de pinturas. García Sáiz ha señalado que los Inventarios Reales formulados a la muerte de Carlos II, en I700, se refirieron a una serie de 24 tablas de la Conquista de México que hoy pertenece al Museo de América de Madrid (fig. 4),77 así como a una representación guadalupana y a una serie de 12 tablas de la Vida de la Virgen. ${ }^{78}$

Dichas menciones se refieren a obras de alto nivel, parecidas a la mayoría de las que alcanzaron el siglo Xx en colecciones españolas. Numerosísimos marcos ricos se hallan en "enconchados" procedentes de dichas colecciones. Muchas obras debieron ser regalos enviados desde la Nueva España, y no respuestas a peticiones

76. Al respecto, véase, por ejemplo, García Sáiz, La pintura colonial..., op. cit., así como García Sáiz y Serrera, "Aportaciones...", op. cit.; Nuria Salazar, "Inmaculada” y "San José con el Niño", en México en el mundo..., op. cit., pp. I48-I 49; Nelly Sigaut, "Virgen de Guadalupe", en Los siglos de oro en los virreinatos de América, Madrid, Sociedad Estatal para la Conmemoración de los Centenarios de Felipe II y Carlos V, I999, pp. 378-38I, e Iberoamérica mestiza. Encuentro de pueblos y culturas, Madrid, Seacex, 2003, p. 254. Ahora bien, algunas de las obras conservadas permanecieron en México. Tal es el caso de una serie de I 2 tablas de las Alegorías del Credo, de Miguel González, ya mencionada, que se divide entre el InAH y el Banco Nacional de México, así como de una Virgen de Guadalupe conservada en la parroquia de San José, en Tlaxcala. Véase "Miguel González", op. cit., así como Toussaint, "La pintura...", op. cit., p. I5.

77. María Concepción García Sáiz, "La conquista militar y los enconchados. Las peculiaridades de un patrocinio indiano", en Los pinceles de la historia. El origen del reino de la Nueva España, México, Consejo Nacional para la Cultura y las Artes/Instituto Nacional de Bellas Artes, I999, pp. III-II3.

78. Ibidem, p. III. 
hechas desde la Península. ${ }^{79}$ Así, la presencia de estas obras en Europa revela el gusto de los grupos de poder novohispanos, más que de los peninsulares.

Ahora bien, Mariana de Neoburgo, la última esposa de Carlos II, regaló "enconchados" al monasterio capuchino de Klausen, en Austria. ${ }^{80}$ Conviene añadir que tal vez esa reina tenía dos biombos "enconchados" que al parecer heredó años después su sobrina Isabel de Farnesio. ${ }^{8 \mathrm{I}}$ Esto permite suponer que algunos miembros de las elites europeas desarrollaron cierto gusto por la producción.

Quizá los grupos de poder peninsulares identificaron el parecido entre los "enconchados" y las lacas asiáticas, pues los documentos que aquéllos escribieron en ocasiones los mencionaron conjuntamente, sin referirse a sus orígenes, ajenos entre sí. ${ }^{82}$ Por ejemplo, en la dote de Catalina de la Cueva había, en I7I7, dos "enconchados" descritos como "láminas embutidas en nácar y relievados y perfilados de oro de la China" ${ }^{83}$ García Sáiz ha señalado que las obras formaron parte de un conjunto de "alaxas de charol" que también incluía "un biombo de charol negro, de doze hojas, charol de la China, muy poblado de oro, de más de media vara de ancho cada oja [sic]", ${ }^{84} \mathrm{y}$ tal descripción permite suponer que se trató de una obra asiática.

Esta mención sugiere que los europeos valoraron la riqueza ornamental de las pinturas "enconchadas" y su parecido con las lacas asiáticas, muy apreciadas en la época. ${ }^{85}$ Así pues, si en efecto ciertos grupos peninsulares gustaron de los "enconchados", tal inclinación debió relacionarse con el interés por las lacas asiáticas.

79. García Sáiz ha observado, en relación con la serie de 24 tablas de la Conquista de México enviada a Carlos II (fig. 4), que "no respondía, como era bastante habitual con los objetos de procedencia americana, a una demanda específica realizada desde la Península, sino a una remesa llevada a cabo desde el propio virreinato". Cfr. ibidem, p. II3.

8o. Dujovne, op. cit., p. 62.

8I. El inventario de los bienes de Isabel de Farnesio, de I745, menciona dos biombos de charol y nácar con pintura fina heredados de su tía Mariana de Neoburgo. Véase Teresa Lavalle Cobo, "El coleccionismo oriental de Isabel de Farnesio", en Oriente en Palacio. Tesoros asiáticos en las colecciones reales españolas, Madrid, Patrimonio Nacional, 2003, p. 2 I 2.

82. García Sáiz, "La conquista militar...”, op. cit., p. I I I.

83. Idem, p. I I I apud. José Luis Barrio Moya, "Nuevas noticias sobre la estancia en Madrid del pintor mallorquín Pedro Onofre Cotto (I7I7)”, Boletín de la Sociedad Arqueológica Lulliana, Palma de Mallorca, núm. 53, 1997, pp. 417-424.

84. Idem.

85. Véase Impey y Jörg, op. cit. 
El que los grupos de poder virreinales enviaran "enconchados" a España permite afirmar que asimismo los encargaron para su propio consumo. La cantidad de obras conservadas en la Península sugiere que el gusto por dichas obras se afianzó entre las elites novohispanas, si bien de modo pasajero. El estudio del tema está pendiente, pues requiere un riguroso análisis documental que aún no se ha emprendido.

Ahora bien, la producción alcanzó a distintos grupos novohispanos. En relación con el tema, la presente investigación comprende el estudio de un muestreo documental basado en inventarios de bienes novohispanos hallados por Manuel Toussaint, ${ }^{86}$ Elisa Vargaslugo, Gustavo $\mathrm{Curiel}^{87}$ y Eugenio del Hoyo. ${ }^{88}$ Asimismo, se analizan documentos consultados en el Archivo General de la Nación de México (en adelante AGN) y en el Archivo de Notarías de Puebla. Es imposible saber cuán representativo resulta este muestreo, cuyos resultados son, desde luego, preliminares y deberán confrontarse con futuros estudios. Con todo, la información es interesante y vale la pena analizarla.

Las menciones a obras de poco valor económico son abundantes en los inventarios de bajo poder adquisitivo de finales del siglo XVII y principios del xviII. Por ejemplo, una carta de dote otorgada por Manuel de Gama a favor de Catarina Guerrero de Villegas tasó "dos láminas de concha: una de Los Dolores y otra de Jesús de la Puebla, en 3 pesos, item, cuatro láminas de concha, veinte reales". ${ }^{89} \mathrm{El}$ inventario de Sebastiana Mereguer de la Roca, de I72I, asentó "Dos tableros de San Ignacio y San Francisco Xavier, sobrepuestos de concha, con sus marcos pintados, en 2 pesos"..$^{\circ}$

Por su parte, el inventario de los bienes de Domingo Antonio Bayón y Bandujo, de I716, se refirió a "Un cuadrito de Nuestra Señora del Rosario, de a tercia, embutido, en 8 reales", ${ }^{1}$ así como a "Un tablero de Felipe Quinto,

86. Toussaint, "Las pinturas...", op. cit., pp. 8-9.

87. Vargaslugo et al., Juan Correa..., op. cit., t. III, y Curiel, "El efímero caudal...”, op. cit.

88. Eugenio del Hoyo, Plateros, platas y alhajas de Zacatecas (1568-1782), Zacatecas, Gobierno del Estado de Zacatecas-Instituto de Cultura de Zacatecas, 1986.

89. Vargaslugo et al., Juan Correa..., op. cit., t. III, pp. I72-I74.

90. Archivo General de la Nación (en adelante AGN, Bienes Nacionales, vol. I40, exp. 3, f. I Iv. Testamento, inventarios y aprecios de los bienes que por fin y muerte de dońa Sebastiana Mereguer de la Roca, viuda de don Antonio Fernández Vela, México (I72I).

91. AGN, Bienes Nacionales, vol. 600, exp. 5, f. 2or. Inventarios y aprecios de los bienes que quedaron del señor canónigo licenciado don Domingo Antonio Bayón y Bandujo, México (I7 I6). Se advierte que el documento no precisa de qué material está embutida la obra. Sin embargo, cabe suponer que se trató del nácar. Recuérdese que, en un documento de I699, Juan González 
embutido en concha, con los escudos de armas, en I2 reales", ${ }^{22}$ mientras que el de Magdalena de Ávila, de I692, mencionó "cinco láminas en concha, labradas, con sus marcos de lo mismo, apreciadas en 30 pesos todas cinco". ${ }^{93}$

Cabe advertir que hay menciones a obras de precios bajos en inventarios ricos. Por ejemplo, el catálogo de los bienes de Diego de Vergara Gaviria registró "Yten, dos tableros de concha con Nuestra Señora de Belén, de poco menos de vara de alto y de ancho tres cuartas, que apreció en tres pesos ambos”, además de "Yten, otros dos tableros de concha, con el Sueño de San Joseph y Adán y Eva en el paraíso, de media vara de alto y menos de dos tercias de ancho, que apreció en dos pesos ambos". ${ }^{94} \mathrm{El}$ documento mencionó, entre numerosas pinturas, "dos láminas, una del Martirio de Santa Catharina y la otra de Santa Úrsula, con sus marcos de ébano iguales, que tienen de alto vara y dos dedos, y de ancho vara menos sesma, sin los marcos, que apreció en doscientos cuarenta pesos ambos". 95

Asimismo, el inventario de los bienes de Juana de Luna y Arellano, de I7I5, registró "Dos tableros embutidos de concha, con los marcos de lo mismo, uno de la Concepción y otro de la Encarnación, a seis pesos. [Al margen] 24 pesos" ${ }^{96}$ Entre las numerosas posesiones del personaje, destaca una colección de 158 pinturas. Las más apreciadas fueron "Nueve países de tres varas de ancho y dos varas y media de alto, con guarnición de flores y frutas y sus molduras doradas, a noventa pesos [cada uno]". ${ }^{97}$

Por otra parte, el inventario de los bienes de Juan Antonio de Vizarrón y Eguiarreta, arzobispo y virrey de la Nueva España de 1747 a I748, registró "Otra dicha [lámina] de concha, con sobrepuestos de plata, marco. En veinte

se comprometió "a hacer y entregar [...] trece Láminas de pintura y embutido". Cfr. Tovar, "Documentos sobre enconchados...”, op. cit., p. I02.

92. AGN, Bienes Nacionales, vol. 600, exp. 5, f. 2or. Inventarios y aprecios de los bienes que quedaron del señor canónigo licenciado don Domingo Antonio Bayón y Bandujo, México (I716).

93. AGN, Bienes Nacionales, vol. I2 19, exp. I2, f. 9r. Testamento de doña Magdalena de Ávila e inventario y aprecio de sus bienes, México (I692).

94. AGN, Inquisición, vol. 748, exp. 4, f. 45 Ir. Inventarios y aprecio de los bienes que quedaron por fin y muerte de don Diego de Vergara Gaviria, secretario de este Santo Oficio; fechos de pedimento de dońa Josefa Navarro, viuda del susodicho (I7 I 2).

95. Idem, f. 450.

96. AGN, Vinculos y Mayorazgos, vol. I88, exp. I, f. 32v. Autos e inventarios de los bienes que quedaron por muerte de la señora dońa Juana de Luna y Arellano (I7I5).

97. Ibidem. 
pesos todo" ${ }^{98}$ Los siete inventarios listaron en total 17 pinturas embutidas de nácar, siete de las cuales poseyeron marcos trabajados de la misma manera. Las referencias a otras nueve obras omitieron los marcos y se mencionaron sólo dos de ellas con marcos pintados. Al parecer, se trata de cenefas que pueden haber estado embutidas de concha.

Llama la atención que múltiples partidas omitan los marcos. Quizá los autores de los inventarios se abstuvieron de mencionar las cenefas que ocuparon un espacio reducido de la superficie pictórica. ${ }^{99}$ Ahora bien, las partidas que sí nombran marcos de concha tasan las obras a precios relativamente bajos. Recuérdese que cinco obras listadas en el inventario de los bienes de Magdalena de Ávila se apreciaron en total en 30 pesos, y que, en el inventario de los bienes de Juana de Luna y Arellano, dos obras con marcos "enconchados" alcanzaron un precio de entre seis y I2 pesos.

En conjunto, los precios de las siete obras con marcos "enconchados" demuestran que éstos se incluyeron en pinturas de presupuesto limitado. Si bien las obras con marcos tuvieron precios bajos, alcanzaron una valuación mayor que la de piezas a cuyos marcos no se hizo referencia. La producción periférica comprendió tanto obras con marcos "enconchados" como desprovistas de ellos, pero el precio aumentó siempre que dichos marcos estuvieron presentes. Esto se advierte, asimismo, en la relación de los bienes del difunto capitán Joseph de Olmedo y Luján, que comprende lo siguiente:

38. Dos tableros de concha de a vara en cuadro con sus marcos de lo mismo, en veinte y cuatro pesos ambos. 24 pesos.

39. Otros dos tableros de concha con sus marcos de lo mismo de dos tercias de largo y más de media vara de ancho del Desposorio y la Encarnación, en diez pesos los dos. Io pesos.

98. AGN, Tierras, vol. 2800, exp. I, f. 4Iv. Diligencias para la valuación e inventarios de los bienes que pertenecieron al finado Juan Antonio de Vizarrón y Eguiarreta, arzobispo y virrey de la Nueva España, Juris, D.F. (I747-I748). Agradezco a Ligia Fernández y Óscar Flores la noticia de este documento.

99. En I77I, Antonio Ponz se refirió a dos series "enconchadas" que representan, respectivamente, las Batallas de Alejandro Farnesio, hoy propiedad de Rodrigo Rivero Lake, y la Conquista de México, que actualmente se divide entre el Museo Franz Mayer de la ciudad de México y el inaH. Ambas series poseen ricas cenefas que el autor soslayó. Véase Toussaint, "La pintura...”, op. cit., p. I4, apud. Antonio Ponz, Viaje de España, seguido de los dos tomos del Viaje fuera de España, María Casto del Rivero (ed.), Madrid, Aguilar [1a. ed., I775-I794.], t. V, pp. 315-316. 
40. Otros dos tableros en media vara de alto y una tercia de ancho con su marco de concha de la Presentación el uno, y el otro de la Visitación, a cinco pesos los dos. Io pesos. [...]

4I. Otros dos tableros de concha con sus marcos de lo propio de media vara de alto y tercia poco más de ancho, de San Pedro y San Pablo, a cuatro pesos apreciados cada uno. 8 pesos.

42. Otros dos tableros de concha de media vara de ancho y una tercia de largo con sus marcos de lo mismo, de San Jerónimo y otro de San Juan, a veinte reales cada uno. 5 pesos.

43. Otros dos tapleros $[s i c]$ de concha de una tercia de alto y de ancho una cuarta con sus marcos de lo mismo, de San Joseph y La Virgen, a diez reales cada uno. 2 pesos. ${ }^{\text {Ioo }}$

Todas las partidas mencionaron marcos de concha y, no obstante, los precios variaron significativamente, pues las dos obras más caras se valuaron en 24 pesos y las más baratas en sólo io reales cada una. Si bien estas últimas debieron ser poco logradas, cabe advertir que las obras que alcanzaron mayor valuación fueron de mucho mayor tamaño que las otras.

Por otro lado, Toussaint publicó menciones provenientes de 20 inventarios novohispanos que se refirieron, en total, a 85 "enconchados". Muchas descripciones son breves, por lo que aquí se abordarán únicamente las que incluyeron referencias a los marcos, o bien a los precios.

Un documento mencionó dos obras con sus "marcos de ébano", ${ }^{\text {IOI }}$ mientras

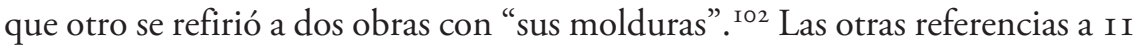
pinturas expresaron "marcos de lo mismo". ${ }^{\text {I03 }}$ Asimismo, se asentó una obra

Ioo. Vargaslugo et al., Juan Correa..., op. cit., t. III, pp. I47-I48. Cabe señalar que el inventario registra doce "enconchados", número importante porque forma parte de un total de I4I pinturas.

ıor. Año de I692. Testamentería de doña Catarina Rodríguez de Cazorla. Dos láminas embutidas en marcos de ébano. Cfr. ibidem, p. 8.

I02. Año de 1698. Testamentería del capitán Juan de Lobera Otáñez. —Dos tableros de concha con sus molduras. Cfr. idem.

I03. Año de I699. Testamentería de Pedro de la Calzada. Tres láminas de concha y maque de diferentes santos con sus marcos de lo mismo. Año de 1727. Bienes de don Alonso Gutiérrez Deza y de su mujer doña Bernarda Básquez, difunta. Dos lienzos y tableritos embutidos de concha con marcos de lo mismo, uno de la Huida a Egipto y el otro de la Encarnación. Seis tableros de a media vara embutidos de concha con marcos de lo mismo ordinarios. Ibidem, pp. 8-9. 
con "su marco embutido". ${ }^{104}$ Es decir que sólo I2 de las 85 obras mencionadas por Toussaint tuvieron marcos "enconchados". Resulta imposible saber si las obras descritas en las partidas que omitieron referirse a los marcos no los tuvieron. En cualquier caso, las menciones sucintas sugieren la existencia de obras sencillas cuya ornamentación debió de haber sido menos lograda que la de muchas obras conservadas.

Cabe añadir que sólo tres partidas mencionaron los precios de las obras. Entre ellas, hay una valuada en 5 pesos, de la que se informó que medía dos ter-

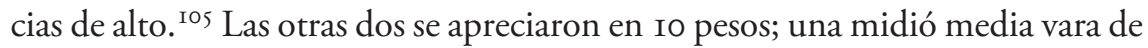
alto y respecto a la otra no se incluyó ninguna información. ${ }^{106}$ Se advierte que los precios son similares a los de ciertas obras con marcos arriba mencionadas.

Es posible que algunos de los "enconchados" mencionados en las partidas anteriores se hayan confeccionado en talleres poco renombrados, a la par que otras pinturas carentes de nácar. Si bien no hay evidencias de que este tipo de trabajo se haya generalizado en los talleres de pintura, no hay duda de que el fenómeno alcanzó mayor difusión de la que sugiere el limitado número de obras y de autores conocidos. Las menciones documentales permiten suponer que el éxito de estas pinturas dio lugar a numerosas obras poco especializadas, de las que los marcos "enconchados" estuvieron a menudo ausentes.

Por otro lado, el inventario de los bienes de la marquesa de San Jorge, de I695, estudiado por Gustavo Curiel, ofrece información valiosa respecto al gusto por las obras entre los grupos de poder locales. ${ }^{107}$ Dicho documento contiene 26 "enconchados", ${ }^{108}$ entre los que destacan diez láminas embutidas de concha

I04. Año de 1727. Testamentería de doña Ana María de la Puente viuda del licenciado don Félix González de Agüero. Un tablero de concha con su marco embutido de Nuestra Señora de la Concepción, ibidem, p. 8.

105. Año de 1704. Testamentería de doña Ángela de Villalobos. Una lámina de concha de dos tercias de alto de Nuestra Señora de la Concepción en 5 pesos, ibidem, p. 8.

106. Idem.

I07. Curiel, "El efímero caudal...", op. cit., p. 77. La conclusión de dicho estudio advierte que, "Junto con los bienes suntuarios de importación, ya sean europeos, orientales o sudamericanos, aparecen otros, hechos en el virreinato de la Nueva Espańa, que fueron indispensables en la costosa carrera por la obtención de una posición social privilegiada. Para ser miembro de las elites era necesario poseer piezas de orfebrería de primer orden, magníficos 'enconchados". Cfr. p. Iог. Curiel también observó que "Los bienes de dońa Teresa conformaron un prototipo de ajuar doméstico (el de la nobleza americana), mismo que imitaron otros miembros de la sociedad virreinal". Idem.

I08. Ibidem, p. 77. 
con marcos de concha y maque, de vara y cuarto de alto, que representaban la Vida de Nuestra Señora la Virgen María y que se valuaron en 500 pesos. ${ }^{109} \mathrm{El}$ elevado precio no deja lugar a dudas sobre la alta calidad del trabajo.

En el documento se mencionó también una lámina de concha, con marco de concha y maque, del Glorioso san Esteban, "que medía poco menos de una vara, apreciada en 25 pesos", ${ }^{110}$ así como Is láminas de concha de "diferentes tamaños y advocaciones, con marcos de maque y concha, apreciadas en I50 pesos". ${ }^{\text {III }}$

Cabe destacar las diferencias de precio entre las distintas pinturas, que se tasaron entre 50 y io pesos cada una, a pesar de que todas tuvieron marcos. Las obras poseyeron diferentes tamaños, lo que explica, en parte, los precios desiguales. Ahora bien, los trabajos debieron de tener una calidad dispar. No hay duda de que el gusto de la acaudalada marquesa de San Jorge por este tipo de pinturas y sus ricos marcos fue común a otros miembros de la elite novohispana, que enviaron a Espańa muchas de las obras que hoy se conservan.

Por otro lado, si bien los marcos embutidos de concha se asociaron principalmente a pinturas "enconchadas", hay algunas noticias de marcos originalmente unidos a pinturas que omitieron el nácar. La primera es una mención de 1704: "Primeramente pusieron por inventario un lienzo de Nuestra Señora de Guadalupe de poco más de dos varas con su marco embutido de concha que avaluó dicho maestro de pintor [Juan Correa] en setenta pesos". ${ }^{\text {II2 La otra }}$ mención es de I7I I y se halla en la ejecución de embargo de los bienes de María Correa de Silva, miembro de la elite zacatecana, ${ }^{113}$ que registra "una Virgen de Guadalupe de a vara, con su marco de concha". ${ }^{I 14}$

I09. Idem.

I Iо. Idem.

II I. Idem.

I I2. "Instrumentos de la testamentería de don Nicolás de Arriaga, quien fue natural y vecino de la ciudad de México, que presentan sus albaceas y herederos universales Juan Bautista López y Nicolás de Eguiara y Eguren”, en Elisa Vargaslugo et al., Juan Correa..., op. cit., t. IV, segunda parte, p. $62 \mathrm{I}$.

I 13 . De acuerdo con Hoyo, "Doña María Correa de Silva era la dama más noble y linajuda que vivía en Zacatecas en aquel entonces. Era [...] descendiente de conquistadores de la Dominica, en las Antillas, y viuda del general don Diego de Medrano, éste descendiente, por línea directa, de los cuatro fundadores de Zacatecas [... Cuando se levantaron los inventarios [...] La riqueza de aquella casa se hallaba muy mermada y dichos inventarios son tan sólo de los restos de una gran fortuna”. Cfr. Eugenio del Hoyo, Plateros..., op. cit., p. 60.

I I4. Idem. 
Se advierte el alto precio de la obra a la que se refiere la primera mención. La pintura es de grandes dimensiones y debe de haber sido de muy buena calidad, al igual que el marco. El documento data de la época en que la producción de "enconchados" estaba vigente. Sin embargo, ignoramos si el marco tuvo un trabajo igual al de los que se unieron a las pinturas embutidas de concha.

El documento zacatecano no se refirió al precio de la obra. Como en el caso anterior, desconocemos si el marco ahí mencionado estuvo pintado y embutido de concha. En caso de que así haya sido, cabe suponer que los grupos de poder de Zacatecas conocieron y gustaron de la riqueza ornamental de dichos marcos a pesar de que el único centro de producción especializada parece haber sido la capital novohispana.

No hay duda de que las pinturas "enconchadas" circularon en otras ciudades novohispanas. Al respecto, cabe mencionar el inventario de Juan Simón de Roa, de Cuernavaca, que en 1720 consignó "Dos láminas de concha de Nuestra Señora de los Dolores y San Ignacio, de tres cuartas, poco menos, a dos pesos cada una, y montan cuatro pesos", ${ }^{115}$ así como la carta de dote de María Pérez de Acosta, de Puebla, de 1727, que registró "Ytem dos láminas guarnecidas de concha, mexicanas, del Esposo y la Esposa, y otras cuatro de lo propio, en cuatro pesos". ${ }^{116}$

Llama la atención que según el último documento las láminas son mexicanas, pues es el único que se refiere a su origen. Se advierte que los precios son bajos, y que la partida omitió mencionar los marcos. Es decir que los "enconchados" de presupuesto reducido no sólo circularon entre los grupos periféricos de la capital, sino también entre los de otras ciudades. Si bien el tema es muy importante, los alcances precisos de la circulación de las obras en las ciudades novohispanas nos resultarán ajenos hasta que no se haga un análisis documental más amplio.

\section{El ámbito de los González. Las series de la Conquista de México}

Como ya se señaló, el estudio de los "enconchados" ha estado ligado a Miguel y Juan González. Ignoramos si hubo especialistas en "enconchados” ajenos a esa familia. Desde principios del siglo xx, Miguel González ha sido objeto de

I I5. AGN, Bienes Nacionales, vol. 24I, exp. I9, f. 43v. Autos e inventarios hechos de los bienes que quedaron por muerte del bachiller don Juan Simón de Roa, presbítero y comisario del Tribunal de la Inquisición, y vecino que fue de la villa de Cuernavaca (I720).

I 16. Archivo de Notarías de Puebla, Notaría I, caja I4, I724-I730, Gregorio de Mendizábal, f. $278 \mathrm{v}$. 
gran interés. Sin embargo, tanto su trabajo como el de Juan González muestran una calidad dispar, por lo que cabe esperar que futuros estudios examinen con detenimiento su producción. ${ }^{\mathrm{II} 7}$

En la actualidad, el nombre de Miguel González se asocia a 85 pinturas embutidas de nácar. ${ }^{\text {II } 8}$ Por su parte, Juan González es autor de al menos 47 obras. ${ }^{\text {II }}$ Es decir que cerca de la mitad de los "enconchados" que se conocen están ligados a estos especialistas. La cifra es incluso mayor si se toma en cuenta que algunas obras anónimas podrían ser de dichos artistas. Para este estudio, las obras de ambos González revisten gran interés, pues muchas poseen ricos

I 7. Algunos de los últimos textos de García Sáiz han avanzado en esta dirección. Véase, especialmente, "Precisiones...", op. cit., pp. I I I-I I6, así como "Nuevos materiales para nuevas expresiones", en Los siglos..., op. cit., pp. I38-I39.

I 18. Miguel González firmó una serie de 24 tablas de la Conquista de México en coautoría con Juan González, que se conserva en el Museo de América de Madrid (fig. 4), así como otras dos series de igual tema y número de tablas, una de las cuales se resguarda en el Museo de Bellas Artes de Buenos Aires (fig. 3) y la otra en una colección particular de Madrid. Véase García Sáiz, "La conquista militar...", op. cit., así como María Josefa Martínez del Río, "La conquista en una serie de tablas enconchadas", en Elisa Vargaslugo et al., Imágenes de los naturales en el arte de la Nueva España. Siglos XVI al XVIII, México, Universidad Nacional Autónoma de México-Instituto de Investigaciones Estéticas/Fomento Cultural Banamex, 2005, pp. 65-66. El especialista es, asimismo, autor de la ya mencionada serie de $\mathrm{I} 2$ tablas de las Alegorías del Credo que se divide entre el Fondo Cultural del Banco Nacional de México y el InaH, así como de una Virgen de Guadalupe firmada en 1692 y conservada en el Museo de América de Madrid.

I 19. Se trata de la serie de 24 tablas de la Conquista de México firmada en I698, en coautoría con Miguel González, que se conserva en el Museo de América de Madrid (fig. 4), así como de una serie de seis tablas de la Defensa de Viena, de I697, resguardada en una colección particular de las Islas Canarias. Juan González es también autor de una serie de al menos ocho tablas de la Vida de san Ignacio de Loyola, dividida en tres colecciones particulares. Asimismo, son de su autoría cuatro tablas de una serie de los Io Mandamientos, de una colección particular; una Adoración de los pastores, de I662, conservada en el Smithsonian American Art Museum, en Washington, D.C.; una Virgen de Balvanera, que se encuentra en el Museo de América, de Madrid; un San Francisco Xavier embarcándose a Asia, de 1703, de una colección particular de Durango; una Epifanía, resguardada en el Museo Soumaya de la ciudad de México, y un Juicio de Guillermo III que fue parte de una serie, de colección particular. Véase Martín Soria, "Painting...", op. cit., p. 3 I3; García Sáiz y Serrera, "Aportaciones...”, op. cit., pp. 78-80; Artes de México, Tesoros de México en España, núm. 22, invierno 1993-1994; Bargellini, "Saint Francis...”, op. cit., y García Sáiz, "Nuevos materiales...", op. cit., pp. I37-I38. Cabe añadir que Soria seńaló que tenía noticia de un San Miguel supuestamente firmado por Juan González en I7I7, de una colección particular mexicana, y que Rodrigo Rivero Lake mencionó que Juan González es autor de un San José cargando al Niño Jesús, también de colección particular. Véase Martín Soria, "Painting...”, op. cit., p. 394, n. 55, así como Rivero Lake, op. cit., p. 284. 
marcos o cenefas. Los mejores marcos de los González se distinguen por la variedad de figuras, el interés por los detalles y cierta tendencia naturalista. Esta investigación no se plantea analizarlos exhaustivamente, sino destacar sus aspectos significativos a partir de una selección de obras.

Todas las series firmadas por los González son de grandes dimensiones y poseen marcos relativamente pequeños, pero muy ricos. Esto se advierte, por ejemplo, en las cinco series de la Conquista de México que se conservan, cuyas cenefas merecen un análisis conjunto, ya que, como ha advertido García Sáiz, las obras se relacionan entre sí. ${ }^{\mathrm{I} 20}$ Entre las pinturas "enconchadas" que han llegado a nosotros, dichas series son las más conocidas, pues han sido objeto de importantes textos. $^{\text {I2I }}$

Tres de las series constan de 24 tablas, y las restantes, de seis tablas cada una. Desde principios del siglo xx se sabía que una de las series de 24 tablas, entonces conservada en el Museo Arqueológico de Madrid, fue firmada por Miguel y

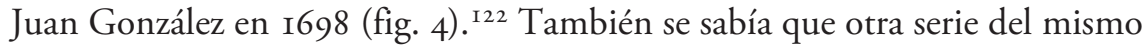
número de tablas, conservada en el Museo de Bellas Artes de Buenos Aires, estaba firmada por Miguel González (fig. 3).

Hasta hace poco tiempo, se creyeron anónimas la tercera serie de 24 tablas, que perteneció a los condes de Moctezuma y que actualmente se divide en dos colecciones particulares en Madrid, y las dos series de seis tablas. Sin embargo, recientemente María Josefa Martínez del Río informó que la serie de la antigua colección Moctezuma está firmada por Miguel González. ${ }^{\text {I23 }}$ En I992, Julieta Ávila reportó que una de las series de seis tablas, hoy dividida entre el INAH y el Museo Franz Mayer de la ciudad de México, muestra la firma "González", aunque no se sabe si corresponde a Tomás, Miguel o Juan González. ${ }^{24}$ Por ello, sólo la serie de seis tablas conservada en el Museo de América de Madrid sería anónima.

I20. García Sáiz, "La conquista militar...”, op. cit., pp. I2 I-I34.

I2 I. Cfr. idem, así como "Precisiones al estudio...”, op. cit. Véase también Dujovne, La Conquista de México por Miguel González, Buenos Aires, Asociación Amigos del Museo Nacional de Bellas Artes, 1972, y Martínez del Río, "La conquista...”, op. cit.

I22. Esta serie fue enviada a Carlos II al poco tiempo de su realización, pues figura en el inventario de bienes hecho a la muerte de ese rey, en i700. Cfr. García Sáiz, "La conquista militar...", op. cit., p. I 13 .

I23. Martínez del Río, "La conquista...", op. cit., pp. 65-66.

I24. Julieta Ávila, "Se localizó una firma semioculta del pintor González en enconchados de México", Boletín del INAH, núm. 39, 1992, pp. 76-79. 
En las tres series de 24 tablas, las cenefas se restringen a la parte superior. El repertorio consiste en un modelo de flores muy esquematizado, hojas, botones de rosa y aves. La serie del Museo de Bellas Artes de Buenos Aires es la que posee las cenefas más sencillas (fig. 3), pese a que éstas son casi idénticas a las de la antigua colección Moctezuma. Esto no sorprende, pues ambas son de Miguel González. ${ }^{\text {I25 }}$ Ahora bien, los González diversificaron las soluciones de los marcos de sus numerosas obras. Es decir, el parecido entre las cenefas de ambas series debió de ser deliberado.

En las cenefas de la serie de Buenos Aires, las figuras son doradas, se encuentran embutidas de nácar y se recortan, dispuestas en dos filas, sobre la rosca negra de un arco de medio punto. La pérdida de capa pictórica es muy notoria sobre los trozos de concha, así como en las aves representadas a cada lado del arco, sobre un fondo inusualmente rojo. Debido al deterioro, abundantes motivos son difíciles de reconocer. Ahora bien, el trabajo original parece haber sido menos cuidadoso que el de la serie que perteneció al conde de Moctezuma.

A diferencia de la serie de Buenos Aires, las cenefas de las tablas de la antigua colección Moctezuma muestran una sola fila de figuras en la rosca del arco. Aquí las figuras son mucho más detalladas y muestran perfiles más definidos. Ambas series poseen la misma paleta, pero en la serie de la antigua colección Moctezuma los colores son brillantes, en contraste con la opacidad de la serie de Buenos Aires.

Si bien compositivamente las cenefas de la antigua colección Moctezuma se relacionan con la serie de Buenos Aires, la solución de las figuras es más próxima a la serie del Museo de América, que firmaron en conjunto Miguel y Juan González (fig. 4). ${ }^{\mathrm{I} 6}$ El parecido es particularmente acentuado con las cenefas de las últimas tablas de la serie del Museo de América. En ambos casos, las flores poseen pétalos de bordes suavizados, así como aves en que, sin llegar a un afán

I25. García Sáiz ha advertido que el trabajo de las superficies pictóricas es muy parecido en ambas series. Véase García Sáiz, "La conquista militar...", op. cit., p. I I5. La misma autora señaló que dicho parecido ya había sido advertido por Dujovne, Las pinturas..., op. cit., p. I I7. Sin embargo, fue García Sáiz quien se detuvo a examinar la relación entre las series, pues dedicó buena parte de su texto a dicho tema.

I26. García Sáiz observó que, pese a que el parecido es particularmente pronunciado entre la serie de la antigua colección Moctezuma y la de Buenos Aires, "la composición de escenas como la que representa la visita de Cortés a Moctezuma, Buenos Aires, y la colección real (Museo de América), nos indica también, con toda claridad, que nos encontramos ante obras estrechamente conectadas". Cfr. "La conquista militar...", op. cit., p. II5. 
naturalista, se muestra interés por los detalles, con trazos que destacan las plumas del pecho o imprimen variaciones a la forma de la cabeza. En comparación con estas figuras, las de la serie de Buenos Aires resultan esquemáticas.

La serie del Museo de América reviste especial interés, por ser la única que presenta dos firmas distintas. Aquí, a diferencia de las dos series anteriores, todo el fondo es negro. La cenefa de la primera tabla se prolonga a la izquierda del espectador, mientras que la de la última tabla lo hace a la derecha. Es decir que cada tabla está enmarcada de manera individual, pero, al exhibirse conjuntamente, toda la serie muestra un solo gran marco pintado, lo que recuerda ciertos biombos de la época, como uno anónimo de io hojas, del siglo xviI, que ostenta en el anverso la Historia de la conquista de México y en el reverso la Vista de la Ciudad de México, y que resguarda el Museo Franz Mayer de la ciudad de México. ${ }^{127}$

Esto sugiere que la serie se hizo para ser exhibida como biombo. Sin embargo, según ha informado García Sáiz, el tasador real que valuó los bienes de Carlos II a su muerte, en I700, describió las obras como "tablas pequeñas que pueden servir de respaldo o Biombo Vajo de esttrado". ${ }^{228}$ La autora observó que en el mismo inventario se listan otras tablas "para biombo". ${ }^{129}$ Es decir que las de esta serie "enconchada" no se consideraron hechas expresamente para convertirse en muebles. Cabe añadir que las tablas representan escenas inconexas, lo cual resulta ajeno a los biombos.

Por otro lado, aunque en las 24 tablas de la serie hay una ornamentación muy similar, las I2 primeras presentan ciertas diferencias respecto a las últimas, en cuanto al número de figuras y la manera de resolverlas. Las flores que pueblan las primeras I 2 tablas poseen entre cinco y seis pétalos, de bordes regulares y puntiagudos, poco naturalistas. Las aves tienden a ser esquematizadas, si bien algunas muestran pequeñas variaciones en la forma de la cabeza (fig. 4).

En contraste, casi todas las flores de las últimas $\mathrm{I} 2$ tablas tienen siete $\mathrm{u}$ ocho pétalos, algunos de los cuales muestran los bordes suavizados e irregulares, lo que sugiere cierto naturalismo. Además, en las aves se aprecia un afán de individualizarlas. Destaca el caso de la tabla 2I, donde el ave de la izquierda se inclina ligeramente hacia adelante, mientras que la del lado opuesto entreabre un poco el pico. También sobresalen las aves representadas en las tablas

I27. La obra se reproduce en el catálogo Los pinceles de la historia..., op. cit., pp. 68-69.

I28. García Sáiz, "La conquista militar...”, op. cit., p. I 3 (las cursivas son mías).

I29. Idem. 
I4, I5, I8 y 20, pues el artista se esmeró en detalles tales como la forma de la cabeza y las plumas, lo que revela un interés por la individualización ajeno a las otras tablas.

La tabla nueve exhibe la rúbrica de Miguel González, mientras que la que cierra el conjunto está firmada por Juan González. Es tentador suponer que Miguel González trabajó las primeras I 2 tablas y Juan González, las últimas I2. Sin embargo, es la segunda mitad de la serie, a la que corresponde la tabla firmada por Juan González, la que muestra figuras parecidas a las de la serie que perteneció al conde de Moctezuma, firmada por Miguel González. Así pues, de momento no es posible extraer conclusiones sobre la manera en que ambos González se dividieron el trabajo de la única serie firmada conjuntamente. Queda claro, sin embargo, que los marcos reservan información valiosa sobre las obras.

Las diferencias entre las cenefas de las tres series mencionadas resultan mínimas si se comparan con las de las dos series de seis tablas que representan la Conquista de México. La ornamentación de cada una de estas últimas siguió caminos individuales, pues en ellas se experimentó con soluciones ajenas a cualquier otro "enconchado" que se conozca. Sin duda, la más interesante es la serie que se divide entre el INAH y el Museo Franz Mayer de la ciudad de México, ${ }^{\mathrm{I} 30}$ pues en ella las cenefas se hallan tanto en el lado superior como en el inferior y siguen la forma adintelada de las tablas. Como en la serie de 24 tablas firmada por Miguel y Juan González, la cenefa se prolonga a la izquierda del espectador, en la tabla que abre el conjunto, y a la derecha, en la última. La obra muestra hojas verdes, muy naturalistas, así como botones de rosas rojas y tulipanes. Destacan las numerosas y coloridas frutas, entre las que se advierten granadas, parecidas a las de las cenefas murales del siglo Xvi.

Especial interés representan los mameyes, frutos tropicales nativos del continente americano. Asimismo, hay frutos de formas irregulares que resulta difícil identificar. La escasez de detalles revela que la solución se basa en intereses ornamentales, no naturalistas. Es notoria la ausencia de racimos de uvas, las únicas frutas habituales en el repertorio de los marcos "enconchados".

La representación de mameyes sugiere el deseo de demostrar que se trata de obras "de la Tierra". ${ }^{13 \mathrm{I}}$ Es posible que la serie, que se encontraba en España en el

I30. Cabe mencionar que dos de estas tablas pertenecen a la colección Mayer y mantienen su carácter exento, mientras que las cuatro que pertenecen al INAH han sido unidas en forma de biombo.

I3I. Véase Curiel, "Al remedo de la China...", op. cit., 3 I6-3 I7. 
siglo XVIII, se haya hecho para enviarla a Europa y, como testimonio de su origen, no sólo se representó la Conquista de México, sino que también se eligió la técnica del "enconchado" y una ornamentación que incluyó frutas americanas. ${ }^{132}$

Es muy interesante que se haya variado el restringido repertorio habitual. Entre las obras aquí registradas, esta serie es la única que muestra frutos americanos y es significativo que, al parecer, la haya confeccionado un especialista. ${ }^{\mathrm{I} 3}$ Es decir, los "enconchados" se alejaron, en ocasiones, de las soluciones de origen japonés que inicialmente impulsaron su desarrollo. ${ }^{\mathrm{I} 4}$ En conjunto, las obras testimonian la creatividad novohispana, y la singular ornamentación de esta serie revela que los autores de "enconchados" exploraron caminos artísticos exclusivos de la Nueva España. ${ }^{135}$

Por su parte, la serie anónima de seis tablas resguardada en el Museo de América de Madrid muestra una ornamentación más sencilla, cuyo repertorio consiste en hojas y un modelo único de flores similares a los tulipanes. Se advierten también unas figuras rojas, cuyas formas recuerdan las hojas de helecho, también presentes, por excepción, en el marco polilobulado de un anónimo San Isidro y el Milagro de la Fuente, del Museo de América de Madrid. ${ }^{136}$

Si bien esta serie no ha sido atribuida a los González, cabe la posibilidad de que esté ligada a esos artistas pues, como ha señalado García Sáiz, las escenas representadas son similares a las de la serie de 24 tablas firmada por ambos

I32. El tema se discute en mi artículo "Mother of Pearl...", op. cit. Cabe añadir que, según ha observado García Sáiz, esta serie pudo haber llegado a los duques del Infantado a través del conde de Galve, virrey de la Nueva Espańa de I688 a I696 y miembro de la casa del Infantado. La misma autora ha señalado que "La más que probable vinculación del conde de Galve y del conde de Moctezuma como comitentes de estas obras [las series de la Conquista de México], y responsables de un patronazgo indiano específico, nos sitúa ante la necesidad de intentar establecer el contexto en el que se producen unas piezas que técnicamente están emparentadas con labores orientales que van imponiendo su presencia en las cortes europeas, y temáticamente actúan como un instrumento de apoyo a las reivindicaciones criollas". García Sáiz, "La conquista militar...”, op. cit., p. II 4 .

I33. En esta serie, también el trabajo de las superficies pictóricas muestra variaciones, pues se incluyen en ella escenas ajenas a las otras series de la Conquista de México que se conservan. Cfr. ibidem, p. I22, así como García Sáiz, "Precisiones...”, op. cit., pp. I I5-I I6.

I34. Los "enconchados" en general y estas tablas en particular ejemplifican lo que Gustavo Curiel ha llamado un "lenguaje achinado", informado en obras asiáticas, que incorporó elementos de origen europeo, así como autóctonos, para dar lugar a una originalidad propia. Cfr. Curiel, "Al remedo...", op. cit., 3 I 7 .

I35. Ocaña, "Mother-of-Pearl...", op. cit.

I36. Véase una reproducción en México en el mundo..., op. cit., p. I 5 I. 
especialistas. ${ }^{137}$ Pese a que la ornamentación no es particularmente rica, la originalidad de sus soluciones ofrece una prueba más de que el interés de los artistas por dotar las obras de detalles que las individualizaran no se halla sólo en las pinturas, sino también en los marcos.

\section{Las obras anónimas especializadas}

Como ya se señaló, se conservan muchas obras anónimas de alto nivel, y es posible que algunas hayan sido creadas por los González. Cabe recordar que desconocemos si hubo otros especialistas en "enconchados". Sin embargo, no todas las obras destacadas fueron producidas por los González, pues ciertos pintores ajenos a su ámbito familiar elaboraron tanto pinturas como marcos ricos. Aquí se señalarán las características más importantes de los marcos anónimos especializados, a la espera de que futuros análisis profundicen en su estudio y permitan agruparlos.

Una Virgen de Guadalupe depositada en el Museo Catedralicio y Diocesano de León, España, muestra a la virgen circundada por medallones que representan las cuatro apariciones (fig. 5). La obra es polilobulada y posee una ornamentación riquísima que se extiende por toda la superficie, con excepción de los lugares ocupados por Guadalupe y los medallones aparicionistas. Entre los "enconchados" aquí registrados, éste es el único cuya ornamentación se adentra en la superficie pictórica, evidenciando la enorme importancia que se concedió a esa parte del trabajo. ${ }^{138}$

La paleta es casi bicromática, pues el fondo negro está poblado por flores, hojas y aves doradas. Los únicos detalles rojos se hallan en los botones de rosa. La obra demuestra hasta qué punto los "enconchados" se consideraron representativos de la Nueva España, pues no parece casual que el tema sea la Virgen de Guadalupe, y que se haya enviado a la Península. Sin duda, el desconocido autor - o el comitente- quiso enfatizar que se trataba de un "enconchado" no sólo por el uso del material, sino también por la ornamentación característica de este tipo de obras. ${ }^{139}$

I37. Véase García Sáiz, "La conquista militar...", op. cit., p. I I5.

I38. Estos comentarios son una versión modificada de los expuestos en "Mother-of-Pearl...", op. cit.

I39. Idem. 
Pese al énfasis ornamental, las figuras no son naturalistas. Más aún, el interés por los detalles resulta limitado. Aun así, la obra es tan original como bella y demuestra la enorme importancia de la ornamentación en los "enconchados". El ejemplo recuerda que, según los tratados europeos de la época, la pintura abarcaba el paisaje que, en los "enconchados", incluía el repertorio de los mar$\cos { }^{\mathrm{I}}{ }^{\circ} \mathrm{E}$ Es decir que, si bien el lenguaje ornamental de la obra remite a la Nueva España, se insertó en un contexto pictórico que se nutrió de concepciones de origen europeo.

También merecen mención los ricos marcos exentos que se unen a una serie de seis tablas de la Vida de la Virgen (fig. 7) y otra de 24 tablas de la Vida de Cristo (fig. 6), ambas del Museo de América de Madrid. En los dos casos, los marcos se ajustan tanto a la paleta como a la iconografía habituales y lucen un abigarramiento de figuras.

Los marcos de la Vida de Cristo poseen flores, hojas y aves, mientras que los de la Vida de la Virgen exhiben también racimos de uvas. En ambas series destacan las aves, que muestran variaciones, sobre todo en la forma de la cabeza. En casi todos los casos, dichas variaciones son menores y no permiten identificar especies reales. A pesar de esto, resulta significativo que los artistas se interesaran por detallar las aves y no las flores, muy esquematizadas en ambas series.

El gusto por el detalle se acentúa particularmente en las aves que pueblan los marcos de la serie de la Vida de Cristo, ya que ostentan una gruesa línea negra en la parte superior de los ojos que sugiere cierta intención de dotarlos de expresividad. ${ }^{14 \mathrm{I}}$ Esta inusual solución se advierte también en algunas de las aves que pueblan las cenefas de una serie anónima de seis tablas de las Batallas de Alejandro Farnesio, de la colección Rodrigo Rivero Lake de la ciudad de México. ${ }^{\mathrm{I} 2}$

I 40. Marcela Salas, Elisa Vargaslugo y José Guadalupe Victoria comentan: "aunque las Ordenanzas de pintores, establecen que, para que un maestro pudiera ser examinado debería saber pintar paisajes — países, según la terminología de la época—, en realidad no se pretendía que lo hicieran como género aparte, ni como representación fiel de la naturaleza. Se sabe también que los tratadistas españoles de la época - Pacheco en particular- se refieren al hecho de que el pintor debía conocer la pintura de flores, frutas y países. Ahora bien, no hay que olvidar que la expresión pictórica novohispana estuvo sometida al dominio intelectual ejercido por los principios de la filosofía escolástica y ésta no concedía categoría artística al paisaje, al menos en el sentido que hoy se entiende; de ahí que su representación siempre haya sido convencional y secundaria". Véase "Paisaje, flora y fauna", en Juan Correa..., Repertorio pictórico, t. IV, segunda parte, op. cit., p. 563.

I4I. Ocaña, "Mother-of-Pearl...", op. cit.

I42. Idem. 
Asimismo, cabe mencionar una Virgen de Guadalupe anónima del Museo de América de Madrid (fig. 9). La obra tiene pequeñas dimensiones y un marco exento que resulta, proporcionalmente, de gran tamaño respecto a la pintura. ${ }^{\text {I43 }}$ Dicho marco deja de lado el abigarramiento de las obras anteriores, si bien mantiene tanto el repertorio como la paleta habituales, pues exhibe botones de rosa rojos, con perfiles dorados, así como pequeñas hojas doradas y otras más grandes, de color verde oscuro. Las flores poseen un botón central embutido de nácar y pintado de rojo, que carece de detalles. Los pétalos son muy numerosos, lobulados, estrechos y regulares, y están perfilados con trazos dorados.

El marco posee aves que muestran cierto afán de individualización, pues vuelven la cabeza al lado opuesto a su cuerpo, o bien exhiben una cresta roja o un largo pico que las distingue de las otras, o dirigen su cuerpo hacia abajo, describiendo un ángulo de 45 grados respecto a la cabeza. Es decir que el énfasis ornamental tuvo lugar en obras de pequeño formato, mucho más sencillas que las series antes comentadas. Así pues, conviene mantener abierta la posibilidad de que algunos marcos como éste hayan sido obra de los especialistas.

\section{La diversificación}

Se conservan al menos dos "enconchados" con ricos marcos exentos creados por pintores de los que se tiene escasa información. Se trata de una Virgen de Guadalupe de Agustín del Pino, que pertenece al Museo Franz Mayer de la ciudad de México (fig. 8), y de una Virgen de Guadalupe confeccionada por un misterioso Rodolfo, que se conserva en el Museo Casa Natal de Jovellanos en Gijón, España. ${ }^{144}$

Las características del marco de Del Pino permiten afirmar que el artista, lejos de copiar las soluciones de los González, desarrolló de manera particular la ornamentación asociada a los "enconchados". La actividad de ese artista está documentada hacia I720, es decir 20 años después de que los González firmaran la mayoría de sus obras. ${ }^{\mathrm{I} 5}$ Cabe recordar que hay abundantes menciones

I43. La obra mide $28 \times 19.5 \mathrm{~cm}$. Véase García Sáiz, La pintura colonial..., op. cit., p. I62.

144. La obra se dio a conocer en 1990. Cfr. García Sáiz y Serrera, "Aportaciones...", op. cit., pp. 69 y 74. Cabe recordar que el marco se comenta en Curiel, "Virgen de Guadalupe...", op. cit., p. I82.

I45. Agustín del Pino es autor de al menos tres "enconchados", de los cuales sólo la Virgen de Guadalupe posee un marco "enconchado". El Museo de América de Madrid y el Denver Art 
a "enconchados" en los ajuares novohispanos de principios del siglo XviII. Es lógico suponer que muchos de esos "enconchados" fueron obra de pintores como Del Pino que, hayan sido o no especialistas, debieron haber tenido una producción diversificada en términos de calidad y presupuesto.

El fondo negro del marco está poblado por botones de rosas, flores, racimos de uvas y aves. Las figuras son doradas, de perfiles negros, y poseen detalles que revelan cierta tendencia naturalista. Los ejemplos más destacados son el tulipán que aparece en el larguero a la derecha del espectador y el ave que pica un pequeño racimo de uvas, un poco arriba de dicha flor (fig. 8). La pintura muestra un tulipán muy parecido al del marco, situado a escasos centímetros de distancia de éste. ${ }^{146}$ Así, la relación entre pintura y marco es muy estrecha. Por eso, Del Pino debió de haber sido el autor de ambas partes de la obra.

Por otro lado, también se conservan marcos extremadamente sencillos, como los que se unen a un San Gregorio, un San Agustin y una Virgen niña con sus padres. ${ }^{147}$ Cabe suponer que estas obras son producto de un encargo conjunto, pues las tres son anónimas, alcanzan las mismas dimensiones, poseen marcos exentos idénticos y se conservan en la iglesia de San Bartolomé de Sevilla.

El habitual fondo negro está poblado por hojas de gran sencillez, formadas por embutidos de nácar que han perdido casi todo el brillo bajo la capa pictórica. En las esquinas hay unos simples motivos trifoliados, también embutidos de nácar, con perfiles dorados. La sencillez de estos marcos sugiere que no son obra de especialistas y, sin embargo, se sujetaron a la ornamentación habitual de los "enconchados".

Es posible que las obras de bajo presupuesto con marcos fueran resultado de un trabajo parecido al que se acaba de comentar. Al parecer, la producción periférica utilizó el código ornamental asociado a los "enconchados". Ello quiere decir que dicho código no fue del uso exclusivo de los especialistas ni de las obras de alto nivel, sino que se aplicó también en creaciones poco notables de numerosos autores hoy desconocidos.

Museum conservan, respectivamente, un San Francisco Xavier y un San Ignacio de Loyola cuyo extremo parecido sugiere que se trató de un encargo conjunto. Véase una reproducción del primero en García Sáiz y Serrera, "Aportaciones...”, op. cit., p. 83, y del segundo en Bargellini, "Saint Francis...", op. cit., p. I89.

I46. Ocaña, "Los marcos enconchados...", op. cit.

I 47. Las obras fueron citadas y reproducidas por García Sáiz y Serrera, "Aportaciones al catálogo...", op. cit., pp. 84-85. 


\section{Conclusiones}

Los "enconchados" aún reservan muchas incógnitas. Sin embargo, cada vez conocemos mejor su problemática. Esas obras se afianzaron en el ámbito pictórico novohispano y, al parecer, alcanzaron su apogeo a finales del siglo XVII y principios del xviII, gracias al trabajo de los especialistas Miguel y Juan González, quienes destacan por los marcos ricos que produjeron. Si bien ambos autores tuvieron logros desiguales - algo frecuente entre los pintores prolíficos-, muchos "enconchados" de alto nivel se les encargaron a ellos.

No hay indicios de que los pintores más renombrados incursionaran en la producción, como supuso Toussaint. En la Nueva España, los "enconchados” se consideraron un segmento especial de la producción pictórica. Múltiples pintores poco reconocidos realizaron obras, pero los más destacados se abstuvieron de hacerlo, pues en la época de auge los "enconchados" destinados a las elites se encargaron principalmente a los González.

Sin embargo, la obra de Del Pino permite descartar que los González hayan sido los únicos en perfeccionar este tipo de trabajo. El fenómeno que dio lugar a los "enconchados" fue complejo y debió tener una evolución paulatina, cuyas primeras etapas desconocemos. Al parecer, los González no realizaron exclusivamente marcos, pese a la enorme importancia de esas partes de las obras. Quizá hubo predilección por el juego lumínico que articuló ambas partes de las obras, a pesar de que el trabajo de los marcos superó, en ocasiones, los logros de las pinturas.

Asimismo, cabe la posibilidad de que los especialistas protegieran su mercado negándose a realizar exclusivamente marcos. Recuérdese que tanto Tomás como Miguel y Juan González parecen haber sido reconocidos por el gremio de pintores. Se sabe muy poco de este tema. Sin embargo, es posible que los agremiados obtuvieran la anuencia para trabajar en los marcos, pues tanto en Europa como en la Nueva España hubo pintores que trabajaron en esas partes de las obras.

La idea de enmarcar las pinturas del modo que se hace en los "enconchados" se nutre de la herencia artística europea. Ahora bien, las pinturas europeas se abstuvieron de apropiarse del repertorio de las lacas japonesas. Es decir, el mestizaje artístico que dio lugar a los "enconchados" remite a cierta manera de concebir la pintura y la ornamentación exclusiva de la Nueva España.

El estudio de los marcos "enconchados" revela que éstos fueron un fenómeno pasajero, pero muy significativo del arte novohispano, a la vez que arroja luz a los evasivos elementos que les dieron origen. Las obras no sólo llaman la 
atención por su belleza distinta: también nos retan a explorar los intrincados caminos que permitieron su desarrollo.

Es posible que los artistas novohispanos se hayan apropiado del repertorio de las lacas namban en superficies de pequeñas dimensiones, como los marcos, al no tener acceso a muchas obras después de que la producción japonesa llegó a su fin a principios del siglo XVII. Desconocemos si la apropiación se planteó desde el principio a partir de la técnica pictórica, pero es muy posible que así haya sido, pues, como ya se señaló, la técnica de las lacas namban es exclusiva de Japón.

El interés novohispano por dichas lacas se articuló con el exacerbado gusto por la ornamentación, y ello dio paso a la conformación de obras propias. El desarrollo de los "enconchados" fue singular, si bien la apropiación del repertorio namban tuvo lugar en un contexto donde el interés por el arte asiático fue muy destacado y tuvo múltiples manifestaciones.

El fenómeno de las pinturas embutidas de nácar fue netamente novohispano y va mucho más allá del mero conocimiento de las obras asiáticas. A finales del siglo XVII, cuando el gusto por estas pinturas alcanzaba su apogeo, la producción de lacas namban tenía largo tiempo de haber concluido. Por eso, el éxito de las obras japonesas y los "enconchados" novohispanos remite a los gustos de generaciones distintas.

Al luchar por construir una identidad artística propia, los novohispanos no vacilaron en hacer suyos ciertos elementos de origen asiático. Esto no sólo se advierte en los "enconchados", sino también en objetos como los biombos y las lacas, que la Nueva España produjo en gran número. Las abundantes apropiaciones locales del arte asiático revelan la voluntad de alejarse artísticamente de Europa y explorar caminos propios. ${ }^{148}$ En el caso de los "enconchados", esto sólo se advierte a cabalidad si se presta atención a sus ricos marcos.

Estas pinturas demuestran que es mucho lo que ignoramos sobre la circulación y el gusto por el arte asiático en la Nueva España. Detrás de la singular belleza de los "enconchados" se encuentra una de las claves para entender la individualidad del arte novohispano, que seleccionó elementos de origen japonés, los incorporó al contexto pictórico local y les imprimió significaciones ajenas tanto a Asia como a Europa.

Si bien las obras que se conservan son de finales del siglo XVII, el desconocido proceso de experimentación debió de durar cerca de media centuria y concernir a dos generaciones. En vista de ello, nuestro conocimiento sobre los "enconcha- 
dos" es fragmentario. La producción difícilmente habría llegado a nosotros de no haber alcanzado tanto éxito entre los grupos de poder, pero las ricas obras conservadas representan sólo un aspecto del fenómeno.

La excepcionalmente alta exportación de "enconchados" sugiere que en el ámbito local las obras se consideraron novohispanas. Las elites locales mandaron numerosos "enconchados" a Europa porque se enorgullecieron de ellos. Es posible decir, por ello, que estas pinturas testimonian un aspecto poco conocido de la identidad artística de los grupos de poder novohispanos de los siglos XVII y XVIII.

Desconocemos hasta qué punto entre los grupos periféricos, predominantemente mestizos, el gusto por la técnica se entendió como una deliberada diferenciación de lo europeo. Los "otros" frente a los que los mestizos quisieron reivindicarse fueron los criollos, más que los peninsulares, de modo que el gusto por las obras pudo tener connotaciones distintas en ambas esferas sociales. De cualquier modo, está claro que la ornamentación, a menudo reservada a los marcos, tuvo una importancia crucial en este tipo de pinturas. El fenómeno posee diversas aristas, lo que demuestra que es digno de un análisis más extenso. \$̊

N.B. Este texto se basa en la tesis "Los marcos enconchados: una vía ornamental novohispana", con la que obtuve el grado de maestría en historia del arte, México, Universidad Nacional Autónoma de México-Facultad de Filosofía y Letras, octubre de 2005. 


\section{Fuentes documentales}

Archivo General de la Nación

\section{Ramo Bienes Nacionales}

Vol. 96, exp. I I, f. 23r, I706. Autos hechos sobre los inventarios y aprecios de los bienes que quedaron por muerte del señor doctor don Pedro de Ávalos y de la Cueva, canónigo magistral de la catedral, a pedimento de sus albaceas.

Vol. I 40, exp. 3, f. I Iv, I72I. Testamento, inventarios y aprecios de los bienes que [se hacen] por fin y muerte de doña Sebastiana Mereguer de la Roca, viuda de don Antonio Fernández Vela.

Vol. 24I, exp. I9, f. 43v, I720. Autos e inventarios hechos de los bienes que quedaron por muerte del bachiller don Juan Simón de Roa, presbítero y comisario del Tribunal de la Inquisición, y vecino que fue de la villa de Cuernavaca.

Vol. 6oo, exp. 5, f. 2or, I7 I6. Inventarios y aprecios de los bienes que quedaron del señor canónigo licenciado don Domingo Antonio Bayón y Bandujo. México.

Vol. I2 I9, exp. I2, f. 9r, I692. Testamento de doña Magdalena de Ávila e inventario y aprecio de sus bienes. México.

\section{Ramo Inquisición}

Vol. 748, exp. 4, f. 45 Ir, I7 I2. Inventarios y aprecio de los bienes que quedaron por fin y muerte de don Diego de Vergara Gaviria, secretario de este Santo Oficio; fechos de pedimento de doña Josefa Navarro, viuda del susodicho.

\section{Ramo Tierras}

Vol. 2800, exp. I, f. 4IV, I747-I748. Diligencias para la valuación e inventarios de los bienes que pertenecieron al finado Juan Antonio de Vizarrón y Eguiarreta, arzobispo y virrey de la Nueva España, Juris, D.F.

\section{Ramo Vinculos y Mayorazgos}

Vol. I88, exp. I, f. 32v, I7 I5. Autos e inventarios de los bienes que quedaron por muerte de la señora dońa Juana de Luna y Arellano.

Archivo de Notarías de Puebla

Notaría I, caja I4, I724-I730, Gregorio de Mendizábal, f. 278v. 